\title{
Organic petrology and geochemistry of mudrocks from the lacustrine Lucaogou Formation, Santanghu Basin, northwest China: application to lake basin evolution
}

Paul C. Hackley, U.S. Geological Survey, MS 956 National Center, Reston VA 20192, phackley@usgs.gov, ph: 703-648-6458

Neil Fishman, Hess Corporation, 1501 McKinney Street, Houston TX 77010

Tao Wu, Warburg Energy Development Limited, Beijing, China

Gregory Baugher, U.S. Geological Survey, MS 956 National Center, Reston VA 20192

\begin{abstract}
Exploration for tight oil in the frontier Santanghu Basin of northwest China has resulted in recent commercial discoveries sourced from the lacustrine Upper Permian Lucaogou Formation, already considered a "world class source rock" in the Junggar Basin to the west. Here we apply an integrated analytical program to carbonate-dominated mudrocks from the Lucaogou Formation in Santanghu Basin to document the nature of organic matter $(\mathrm{OM})$ in the context of an evolving lake system. The organic-rich samples (TOC 2.8-11.4 wt.\%; n=10) were widely spaced from a $\sim 200 \mathrm{~m}$ cored section, interpreted from textural and mineralogical evidence to document transition from a lower under-filled to an overlying balanced-filled lake. Organic matter is dominated by moderate to strongly fluorescent amorphous material with Type I geochemical signature (HI values 510-755; $\mathrm{n}=10$ ) occurring in a continuum from lamellar stringers, $10-20 \mu \mathrm{m}$ thick, some $\geq 1 \mathrm{~mm}$ in length (possible microbial mat; preserved only in lower under-filled section) to finely-disseminated amorphous groundmass intimately intermixed with mineral matrix. Biomarkers for methanotrophs and photosynthetic cyanobacteria indicate a
\end{abstract}


complex microbial consortium. A unicellular prasinophyte green alga(?), similar to Tasmanites in marine rocks, is present as discrete flattened discs 50-100 $\mu \mathrm{m}$ in diameter. Type III OM including vitrinite (some fluorescent) and inertinite also is abundant. Solid bitumen, indicating local kerogen conversion, fills voids and occurs throughout the cored section. Vitrinite reflectance values are $0.47-0.58 \%$, consistent with strong OM fluorescence but may be "suppressed". Other proxies, e.g., biomarker parameters, indicate the Lucaogou Formation is in the early oil window at this location. On average, slightly more amorphous OM and telalginite are present in the lower section, consistent with a shallow, stratified, saline environment with low sediment dilution. More inertinite is present in the upper section, indicating greater terrestrial influx and consistent with higher quartz and plagioclase content (dominantly authigenic chalcedony and albite). Laminated mudstones in the upper section indicate anoxia prevented bioturbation from benthic grazing, also indicating stratified water column conditions. A decrease upsection in authigenic dolomite with reciprocal increase of ankerite/siderite is consistent with decreasing salinity, as is an overall decrease in gammacerane index values. These observations suggest evolution from a shallow, stratified evaporative (saline) setting to a deeper, stratified freshwater basin with higher water input during Lucaogou deposition. The evolution from an under-filled to balance-filled lake in Santanghu Basin is similar to Lucaogou deposition in Junggar Basin, suggesting similar tectonic and climatic controls. Paleoclimate interpretations from other researchers in this area suggested an evolution from semi-arid to humid conditions during the Roadian; we interpret that the evolution from an under-filled to balanced-filled lake seen in our data is in response to climate change, and may represent increased groundwater delivery to the Santanghu Basin.

\section{Key Words}


Lucaogou Formation; Santanghu Basin; lacustrine source rocks; organic petrology; organic geochemistry, Permian

\section{Introduction}

Exploitation of hydrocarbons reservoired in tight rocks (porosity $<10 \%$, permeability $<0.1 \mathrm{mD}$ ) is a topic of global interest following their successful exploitation in North America from the 'shale revolution'. Successful development of these unconventional resources via horizontal drilling and hydraulic fracturing has so far occurred largely in rocks deposited in marine settings. However, in the continental basins of northern China, a generally untested resource may be present in widespread, long-lived lacustrine rocks (e.g., Powell, 1986; Carroll et al., 1992; Peters et al., 1996; Ritts et al., 1999; Hanson et al., 2007; Zhang et al., 2015). Key contrasts in these settings include low thermal maturity and limited areal extent of thermally mature source rocks, thick rock packages, high viscosity waxy hydrocarbons, and poor connectivity to higher porosity reservoir facies (Katz and Lin, 2014).

The Permian Lucaogou Formation is an important lacustrine source rock in the Junggar Basin of northern China, where some samples contain $>20 \mathrm{wt} . \%$ total organic carbon (TOC) content. Previous studies in Junggar Basin have indicated the Lucaogou Formation sourced oils produced from the giant Karamay field in Xinjiang province (Graham et al., 1990; Carroll et al., 1992;

Carroll, 1998). More recent research has focused on the petroleum geology of tight oil accumulations reservoired in Lucaogou siltstones interbedded with source rock mudstone facies in the Jimusaer Sag area of the southeastern Junggar Basin (Xi et al., 2015; Qiu et al., 2016; Cao et al., 2016). 
Lake basin evolution in Junggar Basin has been well-documented through sedimentological and other studies of the Lucaogou Formation and the underlying-overlying section (Carroll et al., 1990, 1995, 2010; Carroll and Bohacs, 1999, 2001). Carroll (1998) described the Lucaogou Formation as primarily laminated dark gray to black mudstones with no evidence for evaporites, whereas Xie et al. (2015) described some evaporitic facies and Carroll et al. (1992) noted "possible evaporite molds". An organic petrology study by Tao et al. (2012) described the Junggar Lucaogou as being composed of lower silty claystones and dolomitic mudstone with tuffs and oil shale, grading upward into oil shale with thin dolomitic marls, argillaceous dolomite and dolomitic mudstones, some with fish bones, followed by an overlying section of dolomitic mudstone, calcareous mudstone and oil shale.

The Lucaogou Formation also is present in the adjacent less-studied Santanghu Basin, a linear feature about $500 \mathrm{~km}$ long and 40-70 km wide, covering $23,000 \mathrm{~km}^{2}$ in northwestern China (Fig. 1). The Santanghu Basin has a complex pre-Permian evolution, superposed over the regional Paleozoic collisional orogenic belt (Zhou et al., 2006; Huang et al., 2013; Xiao and Santosh, 2014). Tectonic isolation resulted in a closed drainage by the Upper Permian and the deposition of carbonate-dominated lacustrine sediments in a sediment-starved intracontinental rift basin with mantle-originated hydrothermal fluids (Li et al., 2012, 2013; Liu et al., 2012a,b, 2015).

Tight oil exploration in Santanghu Basin has resulted in recent (last 15 years) discoveries of medium-heavy low maturity oils in Permian reservoirs sourced from the Lucaogou Formation. Reservoirs are tight sandstones, dolomitic mudstones, tuffaceous dolomites, and carbonates interbedded with Lucaogou mudstones (Liu et al., 2012a,b; Song et al., 2013; Meng et al., 2014), as well as tuffs in the overlying Tiaohu Formation (Liang et al., 2014; Ma et al., 2015, 2016) 
(Fig. 2). Vertical hydrocarbon migration likely occurred over short distances (100-500 m) from the interbedded organic-rich Lucaogou mudrock source facies. Reservoirs are overpressured due to rapid subsidence and hydrocarbon generation. Exploration wells have been primarily vertical with sub-economic oil flow or shows in only 15 of 35 PetroChina wells and commercial flow rates in only 4 wells (Reuters, 2012). Underlying Carboniferous volcaniclastic rocks are also productive (Song et al., 2013).

Recent work by Ma et al. (2015) used organic geochemical and petrological approaches to demonstrate an oil-source correlation between oils reservoired in the tuffaceous Tiaohu Formation and the underlying Lucaogou Formation mudrocks in the Santanghu Basin. This conclusion was based on the absence of good source rock quality in mudrocks of the Tiaohu Formation and dissimilarities in certain biomarker values, whereas similarities in $\beta$-carotane concentrations, gammacerane index, normal sterane distributions and stable $\mathrm{C}$ isotopic composition were observed between Tiaohu oils and Lucaogou source rocks.

Here we consider the organic petrology and geochemistry of Lucaogou core samples from an exploration well in the Malang Sag area of Santanghu Basin. The study focused on organic-rich mudrock facies from the core; other facies were present but not evaluated herein. The objectives of this study were to compare source rock quality to the Lucaogou source rocks in the Junggar Basin and to document Permian lake basin evolution in the Santanghu Basin.

\section{Methods}

A $200 \mathrm{~m}$ section of core was recovered from the exploration well drilled in the Malang Sag (exact location of well is not shown in Fig. 1 due to proprietary constraints). Detailed analytical studies on the full core are proprietary; a small representative subset of mudrock samples 
spanning the depth range of the full core was made available for this study. Samples from conventional core were made into polished circular briquettes of 1 inch diameter for petrographic examination following ASTM D2797 (ASTM, 2015a). Vitrinite and solid bitumen reflectance measurements followed ASTM D7708 (ASTM, 2015b) using a Leica DM4000 microscope equipped with LED illumination and a digital camera detection system. For point-counting of organic matter, a modification of ASTM D2799 (ASTM, 2015c) was used with 250 counts, mineral-inclusive, following maceral nomenclature of ASTM D7708 (ASTM, 2015b) using a Leica DMRX pol microscope equipped with blue and white light illumination. A Zeiss AxioImager microscope with blue and white light illumination was used for imaging and spectral fluorescence measurements following Baranger et al. (1991). X-ray diffraction mineralogical analyses were obtained from low temperature $\left(\sim 120^{\circ} \mathrm{C}\right)$ ashing residues following techniques discussed in Hosterman and Dulong (1989). Weatherford Rock-Eval II pyrolysis and Leco direct combustion total organic carbon (TOC) determinations were performed in a commercial laboratory (Weatherford Laboratories) by standard methods (Espitalié et al., 1977; Peters, 1986) on un-extracted samples. Soxhlet extraction, saturate-aromatic-resin-asphaltene (SARA) fractionation, gas chromatography (GC) analysis of saturate fractions and aromatic fractions, and carbon $(\mathrm{C})$ isotope analysis were made by standard operating methods at the U.S. Geological Survey (USGS; see http://energy.usgs.gov/GeochemistryGeophysics/GeochemistryLaboratories/GeochemistryLabor atoriesMethods.aspx). GC-mass spectrometry analysis of the saturate and aromatic fractions were obtained from Weatherford Laboratories following standard procedures, e.g., as described by Hackley et al. (2013). As described below, analytical data from all methods was compared to proprietary data on the full core and found to be consistent and representative. 


\section{Results and Discussion}

\section{Organic geochemistry from Rock-Eval II pyrolysis}

Rock-Eval II pyrolysis data are listed in Table 1 and shown in Figure 3 in the Hydrogen Index (HI) vs. Oxygen Index (OI) pseudo van Krevelen plot for kerogen typing. The data are consistent with presence of a typical Type I waxy oil-prone lacustrine kerogen with high HI values (508$755 \mathrm{mg} \mathrm{HC/g} \mathrm{TOC),} \mathrm{similar} \mathrm{to} \mathrm{the} \mathrm{Lucaogou} \mathrm{Formation} \mathrm{from} \mathrm{the} \mathrm{Junggar} \mathrm{Basin} \mathrm{(Carroll,} \mathrm{1998).}$ Total organic carbon content is high, ranging from 2.8-11.3 wt.\% indicative of excellent source rock potential (e.g., Peters, 1986; Peters and Cassa, 1994). Pyrolysis yields (S2) of 14-80 mg $\mathrm{HC} / \mathrm{g}$ also indicate excellent source rock potential. Production Index values $>0.1$ in samples 1 ha and 5ha are coincident with the highest $\mathrm{S} 1 * 100 / \mathrm{TOC}$ values and may suggest presence of migrated hydrocarbons. No relationship was observed between TOC and HI; however, a strong linear relationship $\left(\mathrm{r}^{2}=0.94\right)$ between $\mathrm{S} 2$ and TOC suggests that organic matter type was consistent regardless of TOC content (cf Carroll and Bohacs, 2001, Fig. 5D), and that TOC content was controlled mostly by inorganic sediment dilution.

$T_{\max }$ values were calculated to a $R_{o}$ equivalent (Table 1) using the formula of Jarvie et al. (2001). Calculated $\mathrm{R}_{\mathrm{o}}$ values of $0.8-1.1 \%$ suggest peak oil window thermal maturity. However, $\mathrm{T}_{\max }$ generally is a poor predictor of thermal maturity in lacustrine settings because of the predominance of strong cross-linking bonds in the long-chain aliphatic hydrocarbons present in amorphous organic matter (e.g., Tissot et al., 1987). Furthermore, the Jarvie et al. (2001) $R_{\mathrm{o}}$ equivalent formula is based on a dissimilar marine kerogen. There are no published calibrations relating $\mathrm{T}_{\max }$ values from lacustrine kerogen to a $\mathrm{R}_{\mathrm{o}}$ equivalent. $X$-ray diffraction mineralogy 
Results from X-ray diffraction mineralogy analysis are compiled in Table 2 and illustrated in Figure 4. Overall, an upwards decrease in carbonate is accompanied by an increase in the amount of quartz. Within the carbonate types a decrease up-section in dolomite was observed concomitant with an increase in ankerite and siderite concentrations. Calcite is similar in concentration throughout the section. Presence of abundant authigenic carbonate minerals suggests influx of groundwater was an important part of the basin hydrology (cf Renaut and Gierlowski-Kordesch, 2010). The abundance of carbonates in samples across the cored section is consistent with deposition in a closed basin with little sediment influx via fluvial distribution.

Pyrite is present in detectable concentrations and also was observed via petrography. The presence of abundant pyrite is consistent with sulfate reduction in anoxic conditions. Sufficient Fe was present to scavenge $S$ which led to the precipitation of authigenic pyrite.

\section{Organic petrology}

Amorphous organic matter (AOM) dominates the organic assemblage (Table 3; Fig. 5A) occurring as a brightly fluorescent groundmass. This material also is identified as bituminite in some studies (e.g., Fishman et al., 2012; Hackley and SanFilipo, 2016) and is consistent with the oil-prone Type I kerogen indicated by Rock-Eval pyrolysis. The organic groundmass may be derived through multiple pathways, including: 1) original submicroscopic OM (e.g., algae), 2) mechanical and chemical breakdown of larger unicellular algal bodies (telalginite), and 3) bacterial biomass.

Terrestrial organic matter (vitrinite, inertinite) also is prevalent and was observed in every sample (Fig. 5B). Solid bitumen is present in many samples to varying abundances (Fig. 5C) and indicates local hydrocarbon generation or migration. Solid bitumen commonly is embayed to 
authigenic carbonate, indicating it was emplaced in residual porosity after cement precipitation. Solid bitumen abundance is consistent across the cored section with the exception of two higher values towards the top of the cored interval (i.e., samples 4ha, 5ha). Rock-Eval pyrolysis data also confirms the presence of higher amounts of migrated hydrocarbons in this section, i.e., S1*100/TOC for sample 5ha $>200$ (Table 1) interpreted to represent migrated hydrocarbons from local kerogen conversion (cf Liang et al., 2014).

Prasinophyte green algae (planktonic) is present in low abundance in most samples (Fig. 5D), although generally more abundant in the lower part of the core. A wavy anastomosing lamellar alginite (microbial mat facies?) is preserved only in one sample from the lower part of the core (20ha). This material is variously preserved, grading to bituminite, and displays fold-overs (Fig. 5E) suggestive of a cohesive biofilm of extracellular polymeric substances (e.g., Wingender et al., 1999). The presence of bio-laminae $>100 \mathrm{~s}$ of $\mu \mathrm{m}$ in length in microscope view (Fig. 5F) and macro-scale observations from core of similar bio-laminae features supports an in situ origin for microbial facies and implies a benthic photosynthetic community and shallow $(<20 \mathrm{~m})$ water depths. These observations are similar to Tao et al. (2012) who described organic petrology of the Fukang oil shale zone of the Lucaogou Formation in the Junggar Basin and descriptions by Carroll et al. (1992) from southern Junggar. Ma et al. (2015) described the organic petrology of Lucaogou mudrocks as dominated by amorphinite [equivalent to our AOM and bituminite of Fishman et al. (2012), Hackley and SanFilipo (2016)] in concentrations of $\sim 40-75 \%$, followed by lower concentrations of vitrinite and inertinite. To our knowledge, apart from the study of Ma et al. (2015) there are no other published descriptions of organic petrology of the Lucaogou from Santanghu Basin in accessible Western journals. Ma et al. (2015) described the Lucaogou facies as laminated but did not identify specific bio-laminae. 


\section{Thermal maturity from petrographic analyses}

Measured $\mathrm{R}_{\mathrm{o}}$ values (Table 4$)$ were $0.47-0.58 \%$ for vitrinite $(\mathrm{n}=8)$ and $0.26-0.45 \%$ for solid bitumen ( $\mathrm{n}=13)$, showing no change in overall value across the cored section (Fig. 6A). These reflectance values are consistent with strong fluorescence of AOM and telalginite and the PI values from Rock-Eval of $<0.05$, which indicate immature or early mature conditions. However, vitrinite and solid bitumen are atypical and hydrogen-rich, showing fluorescence (compare Fig. 6B-C) and the possibility of suppressed vitrinite reflectance is suggested (e.g., Ujiié et al., 2004). Vitrinite reflectance suppression can occur in sulfate-rich environments with higher $\mathrm{pH}$ (e.g., 6.5-8) favoring sulfate-reducing bacteria; the bacteria cause putrefaction of original organic matter (the vitrinite) along with reduction of sulfate. $\mathrm{Fe}^{2+}$ scavenges reduced $\mathrm{S}^{-}$to form the sulfide mineral pyrite (reviewed in Muyzer and Stams, 2008).

Fluorescence spectra (Fig. 7) of telalginite and AOM were measured on six samples (Table 5). Thermal maturity predictions from the fluorescence spectra are inconsistent with measured $\mathrm{R}_{\mathrm{o}}$ values as $\lambda_{\max }$ values of $555-615 \mathrm{~nm}$ (Table 5) calculate to $\mathrm{R}_{\mathrm{o}}$ equivalent values of $0.50-0.67 \%$. However, using fluorescence spectra to predict thermal maturity in this lacustrine petroleum system is suspect because published correlations are for marine alga in Lower Paleozoic marine rocks (Araujo et al., 2014; Hackley and Kus, 2015) and thermal maturity calibrations for spectral fluorescence in lacustrine settings are not available. The $\lambda_{\max }$ value of $555 \mathrm{~nm}$ for AOM in sample 8 ha is dissimilar to other spectra, although a high wavelength shoulder at about $615 \mathrm{~nm}$ is present. Spectra from telalginite and AOM are similar which defies expectations; AOM is a more labile material and therefore is expected to show a more red-shifted spectrum.

$\delta^{13} C$ isotopes 
Stable $\delta^{13} \mathrm{C}$ isotopic compositions for saturate and aromatic extract fractions were determined for 4 samples (Table 6); saturate $\delta^{13} \mathrm{C}$ isotopic values for sample 1 ha were not reproducible and are not included here. Isotopic compositions of saturates (-30.5 to -33.0) and aromatics (-28.0 to 31.0) are light relative to average lacustrine values (Geomark, 2015), suggesting $\mathrm{CO}_{2}$ is recycled from organic sources in shallow, stratified waters (Lewan, 1986; Bird et al., 1991) and consistent with autotrophic carbon fixation in a microbial mat setting (Schidlowski, 2000). Carbon isotopic values presented here are slightly enriched relative to values reported from Lucaogou mudrocks and Lucaogou-sourced oils reservoired in the overlying Tiaohu Formation (Ma et al., 2015) but similar to Lucaogou samples reported from the Junggar Basin (Carroll, 1998). In Figure 8 we show $\delta^{13} \mathrm{C}$ isotopic values on the Sofer-type plot (Sofer, 1984) relative to average values from several settings (Geomark, 2015). $\delta^{13} \mathrm{C}$ isotopic values are consistent with a saline lacustrine setting.

\section{Biomarker analysis}

Extractable organic matter ranges from $0.22-2.2 \mathrm{wt} . \%$ and SARA fractionation of mudrock extracts showed dominance of saturated components (Table 7), particularly in sample 1ha. This sample contained mostly long-chain waxy hydrocarbons (Fig. 9; maximum at $\mathrm{C}_{27}$ ) typical of most lacustrine oils (e.g., Powell, 1986), which hardened to a solid at room temperature. Although sample 1ha contained a higher amount of thermal distillate (S1) and more extractable organic matter than other samples, the abundance of solid bitumen (Table 3) was similar to the other samples and the basis for the waxy hydrocarbons is unresolved. Samples 8ha and 24ha showed a bimodal $n$-alkane distribution with maxima at $\mathrm{C}_{12}$ and $\mathrm{C}_{27}$ whereas 10ha and 20ha were unimodal with maxima at $\mathrm{C}_{12}$. The presence of high molecular weight waxy $n$-alkanes in crude oil or rock extracts generally is interpreted to indicate terrigenous input to source organic matter 
(Hedberg, 1968); however, non-marine algae also can contain similar $n$-alkane distributions (Moldowan et al., 1985) and the bimodal and unimodal envelopes seen in chromatograms are consistent with a source from lacustrine algae and bacterial biomass (Tegelaar et al., 1989). $\mathrm{Pr} / \mathrm{Ph}$ ratios of $0.85-1.41$ are consistent with lacustrine deposition in a stratified anoxic setting (Didyk et al., 1978) and are identical to values of 0.85-1.40 reported by Ma et al. (2015) (see also Carroll et al., 1992; Carroll, 1998). Values of $\mathrm{Pr} / n-\mathrm{C}_{17} \mathrm{vs.} \mathrm{Ph} / n-\mathrm{C}_{18}$ indicate a transitional position between lacustrine saline and hypersaline conditions on the discriminant plot (Fig. 10), suggestive of mixed organic matter inputs (algal and terrestrial) deposited under reducing conditions. Comparable Lucaogou samples from the Junggar Basin (Carroll et al., 1992) show a wide variation in these ratios. CPI values slightly $>1$ indicate low thermal maturity and also are consistent with organic matter sourced from terrestrial environments. $\beta$-carotane was resolved in all saturate chromatograms (Fig. 9), consistent with elevated salinity in a lacustrine environment and similar to Lucaogou samples from Junggar Basin (Carroll et al., 1992; Carroll, 1998).

Gammacerane was present in high concentrations in all samples (Fig. 11, m/z 191 fragmentograms) and high gammacerane index values (computed as $\mathrm{Ga} / \mathrm{C}_{30} 17 \alpha(\mathrm{H})$-hopane, Table 8; Fig. 12) are consistent with deposition under anoxic, saline and stratified conditions (Sinninghe Damsté et al., 1995). Values display a narrow range in comparison to wider variability seen in Lucaogou samples from the Junggar Basin (Carroll et al., 1992) and are similar to gammacerane index values reported by Miao et al. (2006) for Middle Permian rocks of Xinjiang Province. Average values for lacustrine source rocks deposited in saline conditions are higher but the average lacustrine source rock deposited in fresh water has similar gammacerane index values (Geomark, 2015). (Note: Geomark uses the ratio $\mathrm{Ga} / \mathrm{C}_{31} 22 \mathrm{R} 17 \alpha(\mathrm{H})$ hopane; this results in computed values of 0.57-1.92 for our data, plotting between the average fresh and 
saline values). A general increase in gammacerane index occurs with increasing depth in the Lucaogou core suggesting salinity decreased through time (Table 8), although some variability is present.

Presence of biomarkers $2 \alpha$-methylhopane and $3 \beta$-methylhopane $(\mathrm{m} / \mathrm{z} 205)$ indicate contributions from photosynthetic cyanobacteria and methanogenic archaea, respectively, to the microbial consortium in Lucaogou mudrocks (e.g., Summons et al., 1988; Summons and Jahnke, 1992; Summons et al., 1999; Brocks et al., 2005). $2 \alpha$-methylhopane is present in low abundances (34$117 \mathrm{ppm}$ ) and indicates shallow photic zone deposition. 3ß-methylhopane is present in abundances of 28-311 ppm. Sample 10ha contained the highest abundances of both biomarkers; however no relationships were observed between abundance of these two biomarkers and other organic parameters, e.g., bituminite abundance, TOC, etc.

Normal sterane distributions ( $\alpha \alpha \alpha R, m / z 217)$ show similar proportions of $\mathrm{C}_{29}$ and $\mathrm{C}_{28}$ with lower $\mathrm{C}_{27}$ (Fig. 13; Table 8), suggesting input from terrigenous higher plant material (e.g., Moldowan et al., 1985). Similar distributions were observed from mono-aromatic steroids (m/z 253; not shown). Distributions are tightly clustered relative to the broad field of distributions from the Lucaogou in Junggar (Carroll et al., 1992). Data from Ma et al. (2015) show similar distributions for Lucaogou mudstones and Lucaogou-sourced oils whereas Tiaohu mudstones contain more $\mathrm{C}_{27}$ and show distributions similar to average sterane distributions from lacustrine environments (Geomark, 2015).

Biomarkers indicative of thermal maturity corroborate the early oil window status of the Lucaogou in the Santanghu Basin suggested by petrographic and bulk geochemical analyses. $\mathrm{C}_{29}$ $\alpha \alpha \alpha 20 \mathrm{~S} /(20 \mathrm{~S}+20 \mathrm{R})$ sterane isomerization ratios range 0.44-0.47 (Table 8), indicative of thermal 
maturities in the oil window with equivalent $R_{o}$ values of $\sim 0.8 \%$ (Huang et al., 1990). $C_{29}$ $\beta \beta S / \beta \beta S+\alpha \alpha \mathrm{R}$ ratios of $0.25-0.35$ also suggest early mature conditions and $\mathrm{R}_{\mathrm{o}}>0.65 \% . \mathrm{C}_{32}$ hopane isomerization ratios show equilibrium values of $0.58-0.60$ suggesting early mature conditions and $\mathrm{R}_{\mathrm{o}}$ values of $\sim 0.6 \%$ (Seifert and Moldowan, 1980; Peters et al., 2005).

\section{Variations across the cored section}

Shown in Figure 14 is the variation in abundance of organic matter types in mudrocks across the cored section in the Lucaogou Formation from the Santanghu Basin. With mineral and geochemical proxies discussed herein, these data are interpreted to show a variable but gradual and consistent evolution from shallow, stratified saline conditions to less saline waters during Lucaogou deposition in the Santanghu Basin. AOM and telalginite are preserved in slightly higher abundance (on average) in the lower part of the section, and wavy anastomosing lamellar alginite (benthic microbial mat) is preserved only in the lower part of section (sample 20ha). These observations are consistent with a shallow, stratified saline environment with planktonic telalginite where little sediment dilution allows low turbidity and clear waters to support photosynthetic microbial mat growth in anoxic benthic environments. High carbonate concentrations confirm low sediment input and gammacerane index values are highest in the lower part of the section, indicating more saline conditions. A decrease in dolomite up-section also is consistent with decreasing salinity, assuming dolomite formed by evaporative concentration. A review of lacustrine dolomite by Last (1990) reported $95 \%$ of 50 documented Quaternary occurrences of non-detrital primary dolomite were in salt lakes or sediments interpreted to be deposited in saline conditions. Terrestrial inertinite is more abundant in the upper section, concomitant with greater siliciclastic input, from volcanic airfall or via limited 
surface runoff. Based on these observations, we interpret a more saline lower section and greater fresh water input to the upper section of the core.

Evaporite beds were not observed in any part of the cored section. However, some textures, including bladed features or clots filled with authigenic minerals (Fig. 15A-C) were common in the lower part of the core and decreased markedly in the upper part. The features shown in Figure 15 are interpreted as representing evaporitic textures, which also disrupt bedding in laminated mudrock. Disruption of beds by these features suggests they formed early from synsedimentary pore fluids, when the sediments were largely unconsolidated and readily distortable. Clotting-type carbonate textures also argue for an evaporitic origin.

Thin section petrography revealed an abundance of diagenetic alterations including precipitation of various authigenic cements. In addition to abundant authigenic calcite and dolomite, pyrite, albite, analcime, and chalcedonic quartz also were observed. In Figure 15D euhedral albite laths are observed as a cementing phase and in Figure 15E chalcedony is observed replacing and cementing analcime. Chalcedony also was present as macroscopic void-filling blebs observed in the core. The presence of authigenic albite, analcime, and quartz in the Lucaogou is interesting in that these authigenic minerals have also been noted from other ancient saline lacustrine systems in which abundant silicic volcanic ash was deposited in and altered to form these minerals (cf Turner and Fishman, 1991). Presence of these authigenic minerals in the Lucaogou implies that ash may also have been a component in these sediments, and indeed tuffaceous deposits have been noted in the Lucaogou in the Santanghu Basin (Meng et al., 2014) and bedrock geology surrounding the basin is dominated by Paleozoic volcanic rocks and derivative detritus (e.g., Carroll et al. 1990). 


\section{Conceptual model for Lucaogou deposition in Santanghu Basin}

In this section we evaluate the Lucaogou core data in the context of the Carroll and Bohacs (1999) model for lake basin evolution in response to climatic and tectonic controls. In particular, our data fit a scenario in which Lucaogou sediments were first deposited in an under-filled basin which later evolved to a more balance-filled setting.

In the lower part of the Lucaogou core, chemical, mineral and organic petrographic proxies indicate an under-filled setting during deposition. Evidence includes the common evaporitic textures (Fig. 15A-C), in situ microbial mat facies (Fig. 5E-F), methylhopane biomarkers indicative of photosynthetic bacteria, high gammacerane index values (Fig. 12), high $\beta$-carotane (Fig. 9), and chemical sedimentation dominated by dolomite (Fig. 4). These observations suggest a shallow, stratified, evaporative (saline) facies association in which organic matter was deposited and preserved. The abundance of authigenic carbonate minerals and the absence of evidence for extrabasinal sediment input suggest that groundwater may have been the principal source of water into the lake basin. Groundwater input also is consistent with an under-filled setting in which evaporation is greater than runoff or groundwater/spring influx.

In the upper part of the core, a more balanced-filled scenario dominates. Evidence includes greater abundance of terrestrial organics and fewer examples of evaporitic textures in the core. These proxies are interpreted to indicate that the Lucaogou was deposited under less influence of evaporation and thereby a more balanced-filled lacustrine system in the upper part of the cored interval. Given that carbonate minerals remain a significant component of mineralogy (Fig. 4), groundwater probably continued to contribute to the inflow of the Lucaogou depositional system. The general paucity of detrital silicate minerals within the Lucaogou sediments at this location 
may suggest that the Lucaogou basin had gently sloping margins although more observations from the basin proximal facies are needed to confirm this interpretation. The overall picture that emerges supports an evolution during Lucaogou deposition from an under-filled lake to a more balanced filled system in a clastic-starved setting (Fig. 16).

Per the Carroll and Bohacs (1999) model, the evolution of the Lucaogou basin from under-filled to balance-filled can be accomplished in three ways: 1 . subsidence rate decreases with stable sediment input, 2. sediment input increases with stable subsidence rate, and 3. subsidence rate decreases simultaneously with increase in sediment input. Based on extant paleoclimate interpretations from sedimentological studies by Yang et al. (2007), the Santanghu Basin area experienced a change from semi-arid to humid conditions during the Middle Permian (Roadian). This may indicate that evolution from under-filled to balanced-filled conditions was in response to climate change, and representative of increased humidity and resultant increased water delivery to the basin (Fig. 16). Given that Lucaogou sediments are intrabasinal (dominated by authigenic carbonate phases), increased water delivery may have occurred primarily via groundwater flow. However, work by Yang et al. (2010) south of Junggar Basin suggested the equivalent Lucaogou strata may be older than Middle Permian (upper Sakamarian) as broadly constrained by radiometric dating of over- and underlying rock units.

\section{Summary}

This study included mudrocks from a cored section of organic-rich lacustrine Permian Lucaogou Formation in the Santanghu Basin of northwestern China. An integrated analytical program (Rock-Eval pyrolysis, XRD mineralogy, inorganic and organic petrography, extract analysis) demonstrates an oil-prone source rock with abundant Type I kerogen. Thermal maturity (at this 
location) is in the early oil window. Multiple proxies show an evolution from an under-filled stratified evaporative (saline) setting to a more balance-filled lake basin with higher water input. Similarities to mudrock properties of the time-correlative Lucaogou Formation in the adjacent Junggar Basin (studies by Carroll et al.) suggest a similar tectonic and climatic setting prevailed throughout northwestern China during the Middle-Upper Permian, although precise regional age constraints of the Lucaogou are not available at this time.

\section{Acknowledgment}

Technical reviews by Palma Jarboe (USGS), Alan Carroll (Univ. Wisconsin-Madison) and Henrik Petersen (Maersk Oil) improved this manuscript. Frank Dulong (USGS) provided XRD analyses. Vicky Rocha (Weatherford Laboratories) coordinated some of the geochemical analyses. Augusta Warden, Marc Dreier, and Zach Lowry (USGS) provided rock extract analyses. This research was funded by the USGS Energy Resources Program. Any use of trade, firm, or product names is for descriptive purposes only and does not imply endorsement by the U.S. Government.

\section{References}

Araujo, C.V., Borrego, A.G., Cardott, B., das Chagas, R.B.A., Flores, D., Gonçalves, P., Hackley, P.C., Hower, J.C., Kern, M.L., Kus, J., Mastalerz, M., Mendonça Filho, J.G., Mendonça, J.O., Menezes, T.R., Newman, J., Suarez-Ruiz, I., Sobrinho da Silva, F., Viegas de Souza, I., 2014. Petrographic thermal indices of a Devonian shale maturation series, Appalachian Basin, USA. International Journal of Coal Geology 130, 89-101.

ASTM, 2015a. D2797 Standard practice for preparing coal samples for microscopical analysis by reflected light. Annual book of ASTM standards, petroleum products, lubricants, and fossil fuels; gaseous fuels, coal and coke, v. 5.06. ASTM International, West Conshohocken, PA, http://www.astm.org/Standards/D2797.htm, (Accessed February 14, 2016).

ASTM, 2015b. D7708 Standard test method for microscopical determination of the reflectance of vitrinite dispersed in sedimentary rocks. Annual book of ASTM standards, petroleum 
products, lubricants, and fossil fuels; gaseous fuels, coal and coke, v. 5.06. ASTM International, West Conshohocken, PA, http://www.astm.org/Standards/D7708.htm, (Accessed February 14, 2016).

ASTM, 2015c. D2799 Standard test method for microscopical determination of the maceral composition of coal. Annual book of ASTM standards, petroleum products, lubricants, and fossil fuels; gaseous fuels, coal and coke, v. 5.06. ASTM International, West Conshohocken, PA, http://www.astm.org/Standards/D2799.htm, (Accessed February 14, 2016).

Baranger, R., Martinez, L., Pittion, J.-L., Pouleau, J., 1991. A new calibration procedure for fluorescence measurements of sedimentary organic matter. Organic Geochemistry 17, 467-475.

Bird, M.I., Chivas, A.R., Radnell, C.J., Burton, H.R., 1991. Sedimentological and stable isotope evolution of lakes in the Vestfold Hills, Antarctica. Palaeogeography, Palaeoclimatology, Palaeoecology 84, 109-130.

Brocks, J.J., Love, G.D., Summons, R.E., Knoll, A.H., Logan, G.A., Bowden, S.A., 2005. Biomarker evidence for green and purple sulphur bacteria in a stratified Palaeoproterozoic sea. Nature 437, 866-870.

Cao, Z., Liu, G., Kong, Y., Wang, C., Niu, Z., Zhang, J., Geng, C., Shan, X., Wei, Z., 2016. Lacustrine tight oil accumulation characteristics: Permian Lucaogou Formation in Jimusaer Sag, Junggar Basin. International Journal of Coal Geology 153, 37-51.

Carroll, A.R., 1998. Upper Permian lacustrine organic facies evolution, southern Junggar basin, NW China. Organic Geochemistry 28, 649-667.

Carroll, A.R., Bohacs, K.M., 1999. Stratigraphic classification of ancient lakes: balancing tectonic and climactic controls. Geology 27, 99-102.

Carroll, A.R., Bohacs, K.M., 2001. Lake-type controls on petroleum source rock potential in nonmarine basins. American Association of Petroleum Geologists Bulletin 85, 1033-1053.

Carroll, A.R., Brassell, S.C., Graham, S.A., 1992. Upper Permian lacustrine oil shales, southern Junggar basin, northwest China. American Association of Petroleum Geologists Bulletin 76, 1874-1902.

Carroll, A.R., Graham, S.A., Hendrix, M.S., Ying, D., Zhou, D., 1995. Late Paleozoic tectonic amalgamation of northwestern China: sedimentary record of the northern Tarim, northwestern Turpan, and southern Junggar basins. Geological Society of America Bulletin 107, 571-594.

Carroll, A.R., Graham, S.A., Smith, M.E., 2010. Walled sedimentary basins of China. Basin Research 22, 17-32. 
Carroll, A.R., Liang, Y., Graham, S.A., Xiao, X., Hendrix, M.S., Chu, J., McKnight, C.L., 1990. Junggar basin, northwest China: trapped Late Paleozoic ocean. Tectonophysics 181, 1-14.

Didyk, B.M., Simoneit, B.R.T., Brassell, S.C., Eglinton, G., 1978. Organic geochemical indicators of paleoenvironmental conditions of sedimentation. Nature 272, 216-222.

Espitalié, J., Laporte, J.L., Madec, M., Marquis, F., Leplat, P., Paulet, J., 1977. Méthode rapide de caractérisation des rochès, de leur potential pétrolier et de leur degree d'évolution. Revue de L'Institut Français du Pétrole 32, 23-43.

Fishman, N.S., Hackley, P.C., Lowers, H.A., Hill, R.J., Egenhoff, S.O., Eberl, D.D., Blum, A.E., 2012. The nature of porosity in organic-rich mudstones of the Upper Jurassic Kimmeridge Clay Formation, North Sea, offshore United Kingdom. International Journal of Coal Geology 103, 3250.

GeoMark, 2015. Rock and fluid database. http://geomarkresearch.com/database-products/ (accessed July 20, 2015).

Graham, S.A., Brassell, S., Carroll, A.R., Xiao, X., Demaison, G., McKnight, C.L., Liang, Y., Chu, J., Hendrix, M.S., 1990. Characteristics of selected petroleum source rocks, Xianjiang Uygur autonomous region, northwest China. American Association of Petroleum Geologists Bulletin 74, 439-512.

Hackley, P.C., Kus, J., 2015. Thermal maturity of Tasmanites microfossils from confocal laser scanning fluorescence microscopy. Fuel 143, 343-350.

Hackley, P.C., SanFilipo, J.R., 2016. Organic petrology and geochemistry of Eocene Suzak bituminous marl, north-central Afghanistan: depositional environment and source rock potential. Journal of Marine and Petroleum Geology 73, 572-589.

Hackley, P.C., Ryder, R.T., Trippi, M.H., Alimi, H., 2013. Thermal maturity of northern Appalachian Basin Devonian shales: insights from sterane and terpane biomarkers. Fuel 106, 455-462.

Hanson, A.D., Ritts, B.D., Moldowan, J.M., 2007. Organic geochemistry of oil and source rock strata of the Ordos Basin, north-central China. American Association of Petroleum Geologists Bulletin 91, 1273-1293.

Hedberg, H.D., 1968. Significance of high-wax oils with respect to genesis of petroleum. American Association of Petroleum Geologists Bulletin 52, 736-750.

Hosterman, J.W., Dulong, F.T., 1989. A computer program for semi-quantitative mineral analysis by X-ray powder diffraction. In: Pevear, D.R., Mumpton, F.A. (Eds.), Quantitative mineral analysis of clays. Clay Minerals Society Workshop Lectures 1, p. 38-50. 
Huang, D.D., Li, J., Zhang, D., 1990. Maturation sequence of continental crude oils in hydrocarbon basins in China and its significance. Organic Geochemistry 16, 521-529.

Huang, G., Niu, G., Zhang, Z., Wang, X., Xu, X., Guo, J., Yu, F., 2013. Discovery of 4.0 Ga detrital zircons in the Aermantai ophiolitic mélange, East Junggar, northwest China. Chinses Science Bulletin 58, 3645-3663.

Jarvie, D.M., Claxton, B.L., Henk, F., Breyer, J.T., 2001. Oil and shale gas from the Barnett Shale, Fort Worth basin, Texas. American Association of Petroleum Geologists Annual Meeting Program 10, p. A100.

Katz, B., Lin, F., 2014. Lacustrine basin unconventional resource plays: key differences. Marine and Petroleum Geology 56, 255-265.

Last, W.M., 1990. Lacustrine dolomite: an overview of modern, Holocene, and Pleistocene occurrences. Earth Science Reviews 27, 221-263.

Lewan, M.D., 1986. Stable carbon isotopes of amorphous kerogens from Phanerozoic sedimentary rocks. Geochimica et Cosmochimica Acta 50, 1583-1591.

Li, S., Zhao, G., Dai, L., Liu, X., Zhou, L., Santosh, M., Suo, Y., 2012. Mesozoic basins in eastern China and their bearing on the deconstruction of the North China Craton. Journal of Asian Earth Sciences 47, 64-79.

Li, W., Liu, Y., Dong, Y., Zhou, X., Liu, X., Li, H., Fan, T., Zhou, D., Xu, X., Chen, J., 2013. The geochemical characteristics, geochronology and tectonic significance of the Carboniferous volcanic rocks of the Santanghu area in northeastern Xinjiang, China. Science China Earth Sciences 56, 1318-1333.

Liang, H., Li, X., Ma, Q., Liang, H., Luo, Q., Chen, X., Bai, G., Zhang, Q., Meng, Y., 2014. Geological features and exploration potential of Permian Tiaohu Formation tight oil, Santanghu basin, NW China. Petroleum Exploration and Development 41, 616-627.

Liu, B., Lü, Y., Meng, Y., Li, X., Guo, X., Ma, Q., Zhao, W., 2015. Petrologic characteristics and genetic model of lacustrine lamellar fine-grained rock and its significance for shale oil exploration: a case study of Permian Lucaogou Formation in Malang sag, Santanghu Basin, NW China. Petroleum Exploration and Development 42, 656-666.

Liu, B., Lü, Y., Zhao, R., Tu, X., Guo, X., Shen, Y., 2012a. Formation overpressure and shale oil enrichment in the shale system of Lucaogou Formation, Malang Sag, Santanghu Basin, NW China. Petroleum Exploration and Development 39, 744-750.

Liu, Y., Jiao, X., Li, H., Yuan, M., Yang, W., Zhou, X., Liang, H., Zhou, D., Zheng, C., Sun, Q., Wang, S., 2012b. Primary dolostone formation related to mantle-originated exhalative 
hydrothermal activities, Permian Yuejingou section, Santanghu area, Xinjiang, NW China. Science China Earth Sciences 55, 183-192.

Ma, J., Huang, Z., Gao, X., Chen, C., 2015. Oil-source rock correlation for tight oil in tuffaceous reservoirs in the Permian Tiaohu Formation, Santanghu Basin, northwest China. Canadian Journal of Earth Sciences 52, 1014-1026.

Ma, J., Huang, Z., Liang, S., Liu, Z., Liang, H., 2016. Geochemical and tight reservoir characteristics of sedimentary organic-matter-bearing tuff from the Permian Tiaohu Formation in the Santanghu Basin, northwest China. Marine and Petroleum Geology 73, 405-418.

Meng, Y., Zhu, H., Li, X., Wu, C., Hu, A., Zhao, Z., Zhang, L., Xu, C., 2014. Thermodynamic analyses of dolomite dissolution and prediction of the zones of secondary porosity: a case study of the tight tuffaceous dolomite reservoir of the second member, Permian Lucaogou Formation, Santanghu Basin, NW China. Petroleum Exploration and Development 41, 754-760.

Miao, J., Kou, H., Zhou, L., Han, Z., 2006. Sedimentary environments of organic matter from Middle Permian source rocks in northern Xinjiang, China. Chinese Journal of Geochemistry 25, 258-265.

Moldowan, J.M., Seifert, W.K., Gallegos, E.J., 1985. Relationship between petroleum composition and depositional environment of source rocks. American Association of Petroleum Geologists Bulletin 69, 1255-1268.

Muyzer, G., Stams, A.J.M., 2008. The ecology and biotechnology of sulfate-reducing bacteria. Nature Reviews Microbiology 6, 441-454.

Peters, K.E., 1986. Guidelines for evaluating petroleum source rock using programmed pyrolysis. American Association of Petroleum Geologists Bulletin 70, 318-329.

Peters, K.E., Cassa, M.R., 1994. Applied source rock geochemistry. In: Magoon, L.B., Dow, W.G. (eds.), The petroleum system-from source to trap: American Association of Petroleum Geologists Memoir 60, p. 93-120.

Peters, K.E., Walters, C.C., Moldowan, J.M., 2005. The biomarker guide, volume 2: biomarkers and isotopes in petroleum exploration and earth history. Cambridge University Press, 1155 p.

Peters, K.E., Cunningham, A.E., Walters, C.C., Jigang, J., Zhaoan, F., 1996. Petroleum systems in the Jiangling-Dangyang area, Jianghan Basin, China. Organic Geochemistry 24, 1035-1060.

Powell, T.G., 1986. Petroleum geochemistry and depositional setting of lacustrine source rocks. Journal of Marine and Petroleum Geology 3, 200-219. 
Qiu, Z., Tao, H., Zou, C., Wang, H., Ji, H., Zhou, S., 2016. Lithofacies and organic geochemistry of the Middle Permian Lucaogou Formation in the Jimusaer Sag of the Junggar Basin, NW China. Journal of Petroleum Science and Engineering 140, 97-107.

Renaut, R.W., Gierlowski-Kordesch, E.H., 2010. Lakes. In: Dalrymple, R., James, N. (Eds.), Facies Models. Geological Association of Canada, Toronto, pp. 541-575.

Reuters, 2012. PetroChina in talks with Shell, Hess to explore shale oil. Reuters, Beijing. http://reuters.fr/article/idUKL3E8F50OO20120405 (Accessed April 22, 2015).

Ritts, B.D., Hanson, A.D., Zinniker, D., Moldowan, J.M., 1999. Lower-Middle Jurassic nonmarine source rocks and petroleum systems of the northern Qaidam Basin, northwest China. American Association of Petroleum Geologists Bulletin 83, 1980-2005.

Schidlowski, 2000. Carbon isotopes and microbial sediments. In: Riding, R.E., Awramik, S.M. (Eds.), 2000. Microbial sediments. Springer-Verlag, Berlin, p. 84-95.

Seifert, W.K., Moldowan, J.M., 1980. The effect of thermal stress on source rock quality as measured by hopane stereochemistry. Physics and Chemistry of the Earth 12, 229-237.

Sinninghe Damsté, J.S., Kenig, F., Koopmans, M.E., Köster, J., Schouten, S., Hayes, J.M., de Leeuw, J.W., 1995. Evidence for gammacerane as an indicator of water column stratification. Geochimica et Cosmochimica Acta 59, 1895-1990.

Sofer, Z., 1984. Stable carbon isotope compositions of crude oils: application to source depositional environments and petroleum alteration. American Association of Petroleum Geologists Bulletin 68, 31-49.

Song, D., He, D., Wang, S., 2013. Source rock potential and organic geochemistry of Carboniferous source rocks in Santanghu Basin, NW China. Journal of Earth Science 24, 355370 .

Summons, R.E., Powell, T.G., Boreham, C.J., 1988. Petroleum geology and geochemistry of the Middle Proterozoic McArthur Basin, northern Australia: III. Composition of extractable hydrocarbons. Geochimica et Cosmochimica Acta 52, 1747-1763.

Summons, R.E., Jahnke, L.L., 1992. Hopenes and hopanes methylated in ring A: a correlation of the hopanoids from extant methyltrophic bacteria with their fossil analogues. In: Moldowan, J.M., Albrecht, P., Philp, R.P., (Eds.), Biological markers in sediments and petroleum. PrenticeHall, Englewood Cliffs, NJ, p. 182-200.

Summons, R.E., Jahnke, L.L., Hope, J.M., Logan, G.A., 1999. 2-methylhopanoids as biomarkers for cyanobacterial oxygenic photosynthesis. Nature 400, 554-557. 
Tao, S., Wang, Y., Tang, D., Wu, D., Xu, H., He, W., 2012. Organic petrology of the Fukang Permian Lucaogou Formation oil shales at the northern foot of Bogda Mountain, Junggar Basin, China. International Journal of Coal Geology 99, 27-34.

Tegelaar, E.W., Matthezing, R.M., Jansen, J.B.H., Horsfield, B., de Leeuw, J.W., 1989. Possible origin of n-alkanes in high-wax crude oils. Nature 342, 529-531.

Tissot, B.P., Pelet, R. Ungerer, P.H., 1987. Thermal history of sedimentary basins, maturation indices, and kinetics of oil and gas generation. American Association of Petroleum Geologists Bulletin 71, 1445-1466.

Turner, C.E., Fishman, N.S., 1991. Jurassic Lake T'oo'dichi': a large alkaline, saline lake, Morrison Formation, eastern Colorado Plateau. Geological Society of America Bulletin 103, 538-558.

Ujiié, Y., Sherwood, N., Faiz, M., Wilkins, R.W.T., 2004. Maturity and suppressed vitrinite reflectance for Neogene petroleum source rocks of Japan. American Association of Petroleum Geologists Bulletin 88, 1335-1356.

Wingender, J., Neu, T.R., Flemming, H.-C., 1999. What are bacterial extracellular polymeric substances? In: Wingender, J., Neu, T.R., Flemming, H.-C., (Eds.), Microbial extracellular polymeric substances: characterization, structure and function. Springer-Verlag, Berlin Heidelberg, p. 1-19.

Xi, K., Cao, Y., Zhu, R., Shao, Y., Xue, X., Wang, X., Gao, Y., Zhang, J., 2015. Rock types and characteristics of tight oil reservoir in Permian Lucaogou Formation, Jimusaer sag. Acta Petrolei Sinica 36, 1495-1507.

Xiao, W., Santosh, M., 2014. The western Central Asian Orogenic Belt: a window to accretionary orogenesis and continental growth. Gondwana Research 25, 1429-1444.

Xie, X., Borjigin, T., Zhang, Q., Zhang, Z., Qin, J., Bian, L., Volkman, J.K., 2015. Intact microbial fossils in the Permian Lucaogou Formation oil shale, Junggar basin, NW China. International Journal of Coal Geology 146, 166-178.

Yang, W., Feng, Q., Liu, Y., Tabor, N., Miggins, D., Crowley, J.L., Lin, J., Thomas, S., 2010. Depositional environments and cyclo- and chronostratigraphy of uppermost CarboniferousLower Triassic fluvial-lacustrine deposits, southern Bogda Mountains, NW China: a terrestrial paleoclimatic record of mid-latitude NE Pangea. Global and Planetary Change 73, 15-113.

Yang, W., Liu, Y., Feng, Q., Lin, J., Zhou, D., Wang, D., 2007. Sedimentary evidence of EarlyLate Permian mid-latitude continental climate variability, southern Bogda Mountains, NW China. Palaeogeography, Palaeoclimatology, Palaeoecology 252, 239-258. 
Zhang, M., Ji, L., Wu, Y., He, C., 2015. Palynofacies and geochemical analysis of the Triassic Yanchang Formation, Ordos Basin: implications for hydrocarbon generation potential and the paleoenvironment of continental source rocks. International Journal of Coal Geology 152, 159176.

Zhou, D., Liu, Y., Xing, X., Hao, J., Dong, Y., Ouyang, Z., 2006. Formation of the Permian basalts and implications of geochemical tracing for paleo-tectonic setting and regional tectonic background in the Turpan-Hami and Santanghu basins, Xinjiang. Science China Earth Sciences 584-596. 


\section{List of Figures}

Figure 1. Map of Santanghu Basin, northern China. Modified from Song et al. (2013).

Figure 2. Stratigraphic column for Santanghu Basin showing Permian Lucaogou Formation, underlying Carboniferous Kalagang Formation, and overlying Permian Tiaohu Formation. Modified from Liang et al. (2014). Note that the depth and log traces are not specific or representative of the exploration well and cored section discussed herein and are generalized from the discussion of Liang et al. (2014).

Figure 3. Pseudo van Krevelen HI vs OI plot from Rock-Eval pyrolysis II data. A histogram showing total organic carbon (TOC) content of the samples is shown as an inset.

Figure 4. X-ray diffraction mineralogy versus depth for quartz and total carbonates.

Figure 5. Photomicrographs of organic petrology features. All photomicrographs are under oil immersion. A. Brightly fluorescent amorphous organic matter groundmass under incident blue light illumination. B. Same field as A under white incident light illumination showing scattered vitrinite (gray) and inertinite (whitish gray) fragments. C. Solid bitumen (gray) embayed against euhedral authigenic carbonate under white incident light. D. Prasinophyte alga under incident blue light. E. Lamellar alginite in sample 20ha showing fold-overs suggestive of a cohesive microbial mat facies under incident blue light. F. Low magnification view of lamellar alginite microbial mat(?) facies in sample 20ha under incident blue light.

Figure 6. A. Vitrinite and solid bitumen reflectance versus depth. B. Vitrinite (dark gray) occurring in bimaceral fragment with inertinite (bright gray) in incident white light under oil immersion. C. Same field as B under incident blue light showing fluorescence of vitrinite.

Figure 7. Example fluorescence spectra from amorphous organic matter in sample 8ha (A) and telalginite in sample 13 ha $(\mathrm{B})$.

Figure 8. $\delta^{13} \mathrm{C}$ isotopic data for Lucaogou samples shown in comparison to average values from known depositional environments (Geomark, 2015) and other Permian source rock extract and oil data from the Santanghu Basin (Ma et al., 2015). Average values from Geomark (2015) filtered by using data only with known depositional environment, non-biodegraded and low to moderate thermal maturity.

Figure 9. Saturate fraction gas chromatograms. Normal alkanes are labeled by $\mathrm{C}$ number, e.g., 13 is $\mathrm{C}_{13} n$-alkane; $\mathrm{i}-18$ is $18 \mathrm{C}$ isoprenoid.

Figure 10. Plot of $\mathrm{Pr} / n-\mathrm{C}_{17}$ vs. $\mathrm{Ph} / n-\mathrm{C}_{18}$ showing Lucaogou data from this study relative to data from the Lucaogou in Junggar Basin (Carroll et al., 1992) and average values for nonbiodegraded, low to moderate thermal maturity source rock extracts from known depositional environments (Geomark, 2015). 
Figure 11. Saturate fraction fragmentograms for $\mathrm{m} / \mathrm{z} 191,217,218$. A key to labeled peaks is provided in Table 9.

Figure 12. Gammacerane Index $\left(\mathrm{Ga} / \mathrm{C}_{30} 17 \alpha(\mathrm{H})\right.$-hopane for our data) vs. $\mathrm{Pr} / \mathrm{Ph}$ values showing Lucaogou data from this study relative to data from the Lucaogou in Junggar Basin (Carroll et al., 1992) and average values for non-biodegraded, low to moderate thermal maturity source rock extracts from known depositional environments (Geomark, 2015; note that Geomark uses $\mathrm{Ga} / \mathrm{C}_{31}$ 22R $17 \alpha(\mathrm{H})$ hopane). Source rock extract data from Middle Permian rocks analyzed by Miao et al. (2006) from northern Xinjiang province (Junggar, Turpan and Ili basins) also shown.

Figure 13. Normal sterane distributions showing Lucaogou data from this study relative to data from the Lucaogou in Junggar Basin (Carroll et al., 1992) and average values for nonbiodegraded, low to moderate thermal maturity source rock extracts from known depositional environments (Geomark, 2015). Data for Middle Permian source rocks and oils from Ma et al. (2015) also shown.

Figure 14. Variation in organic matter type abundances with depth on a vol.\% basis.

Figure 15. Photographs of evaporative rock textures and authigenic minerals from transmitted light petrography. A. Thin section showing displacement and disruption of bedding by blades containing authigenic calcite and pyrite. B. Core sample (pen cap is approximately $5 \mathrm{~cm}$ in length) in which blades containing authigenic calcite cut across and disrupt bedding. C. Core sample (pen is approximately $15 \mathrm{~cm}$ in length) containing clots of authigenic calcite. D. Authigenic albite laths (photograph taken under cross-polarized light). E. Chalcedonic quartz that locally is an authigenic cement (photograph taken under cross-polarized light).

Figure 16. Carroll and Bohacs (1999) model for lake basin types with superposed evolution of Lower to Upper Lucaogou facies (orange arrow) as discussed in the text. 


\section{List of Tables}

Table 1. Rock-Eval II pyrolysis and Leco direction combustion data.

Table 2. X-ray diffraction mineralogy data in wt.\%.

Table 3. Petrographic data in vol.\%.

Table 4. Vitrinite and solid bitumen reflectance data.

Table 5. Spectral data from Lucaogou samples.

Table 6. Stable $\delta^{13} \mathrm{C}$ isotope data.

Table 7. SARA fractionation data.

Table 8. Saturate gas chromatography and gas chromatography-mass spectrometry data.

Table 9. Abbreviations for labeled biomarker compounds in Figure 11. 

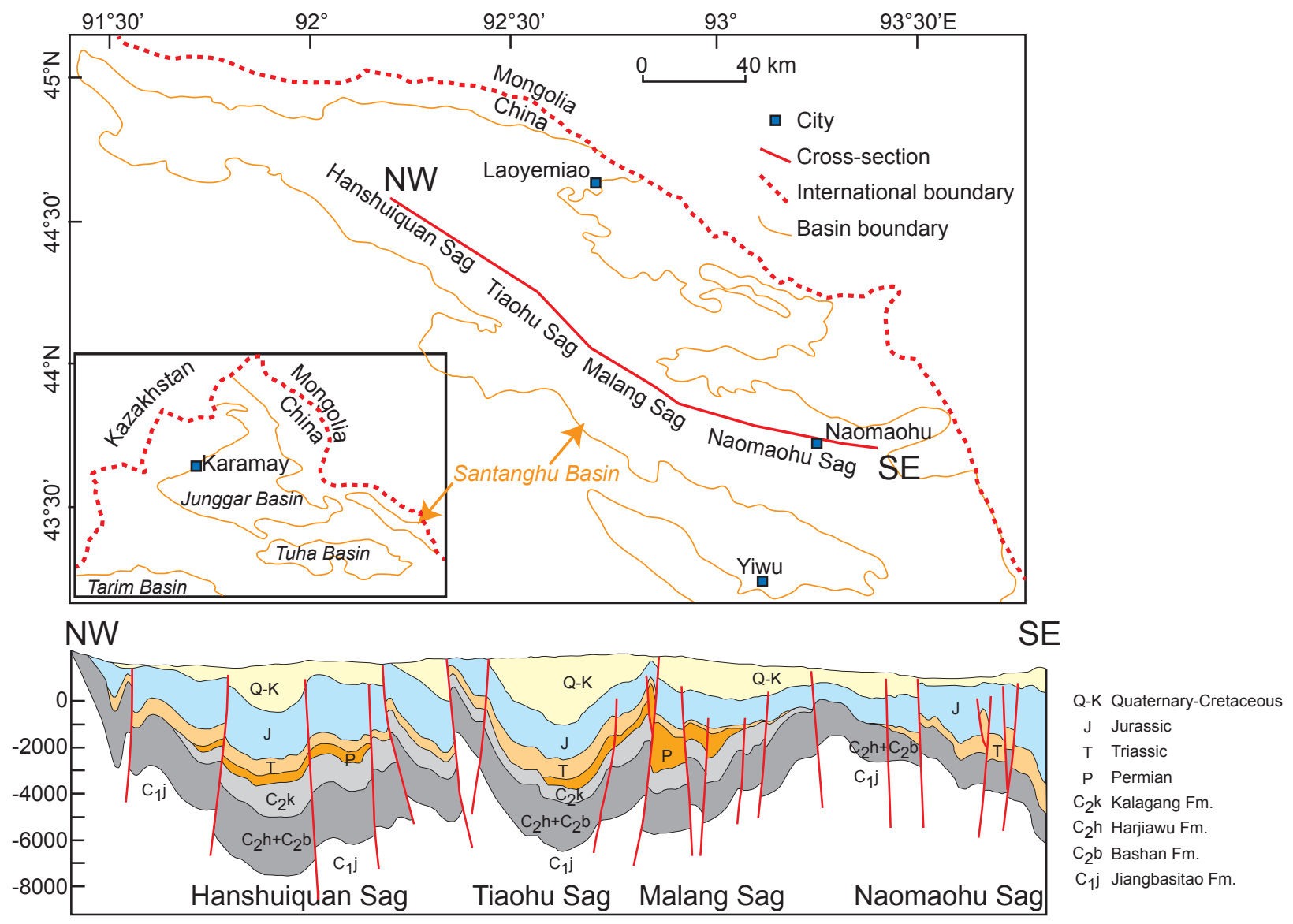

Fig. 1 


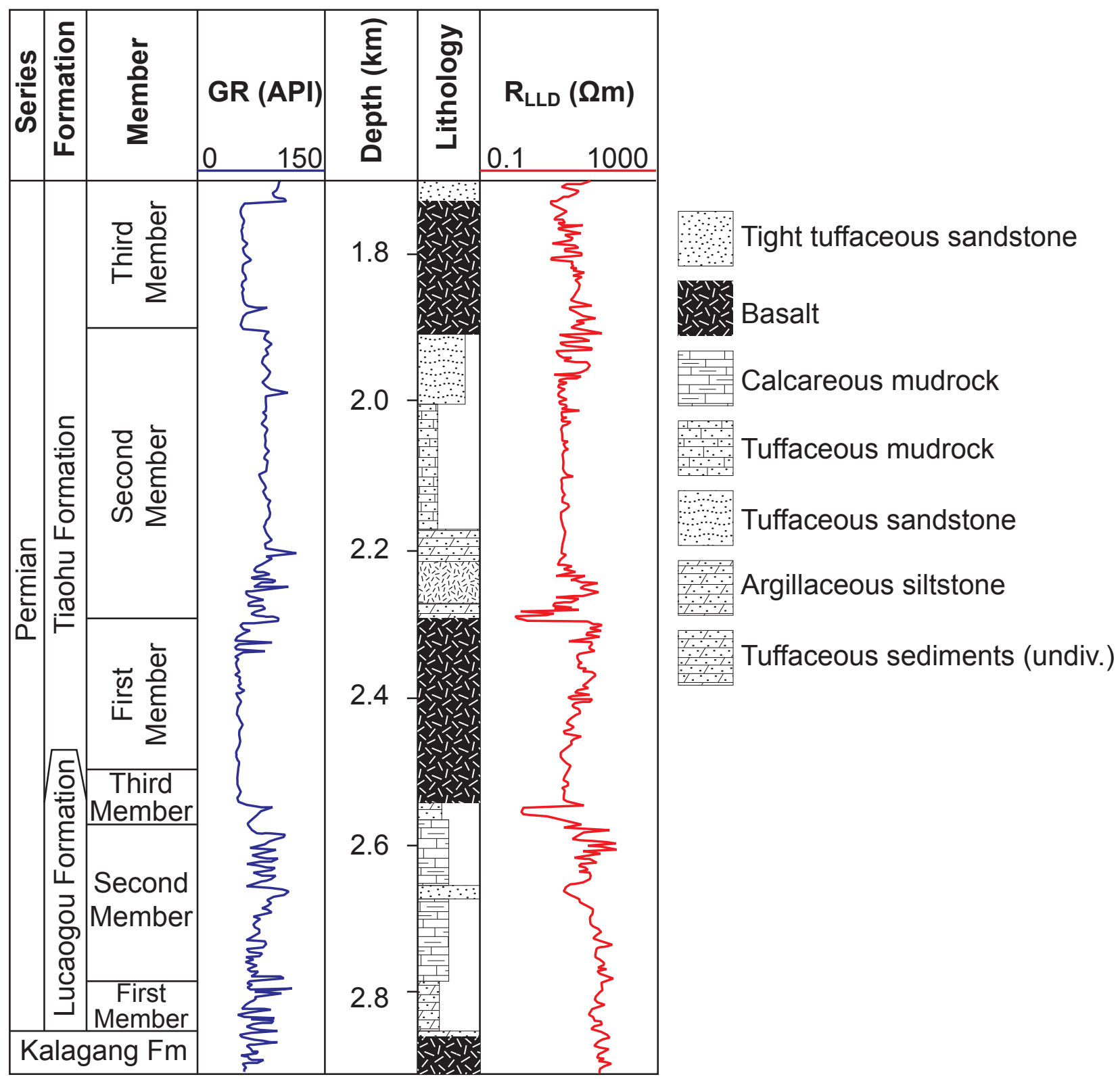

Fig. 2 


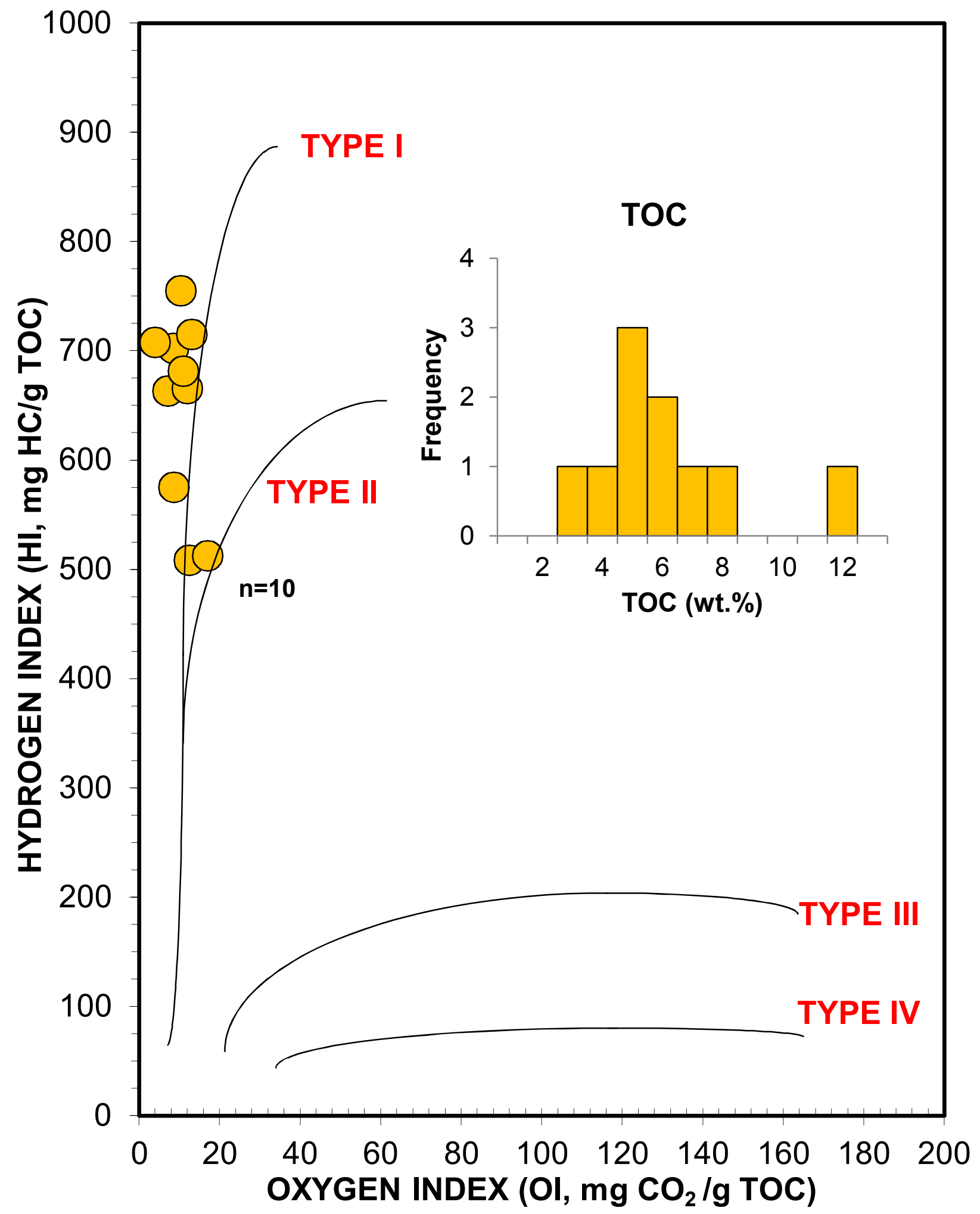

Fig. 3 


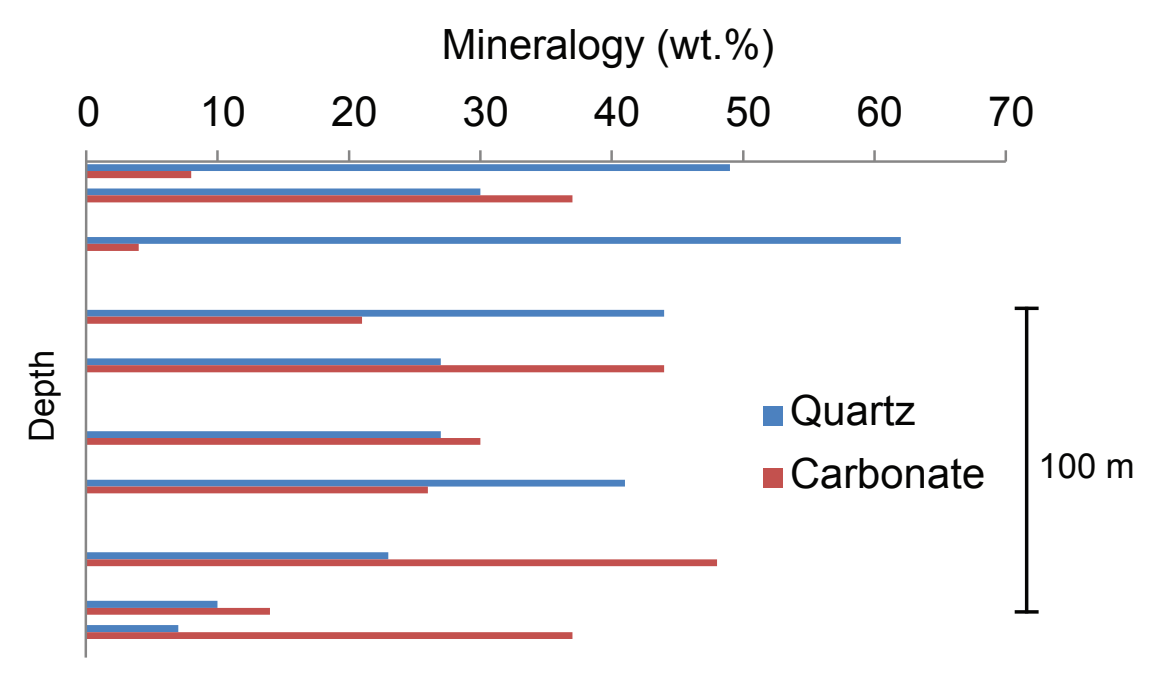

Fig. 4

Fin

\section{4}

ineralogy (wt.\%)

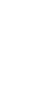



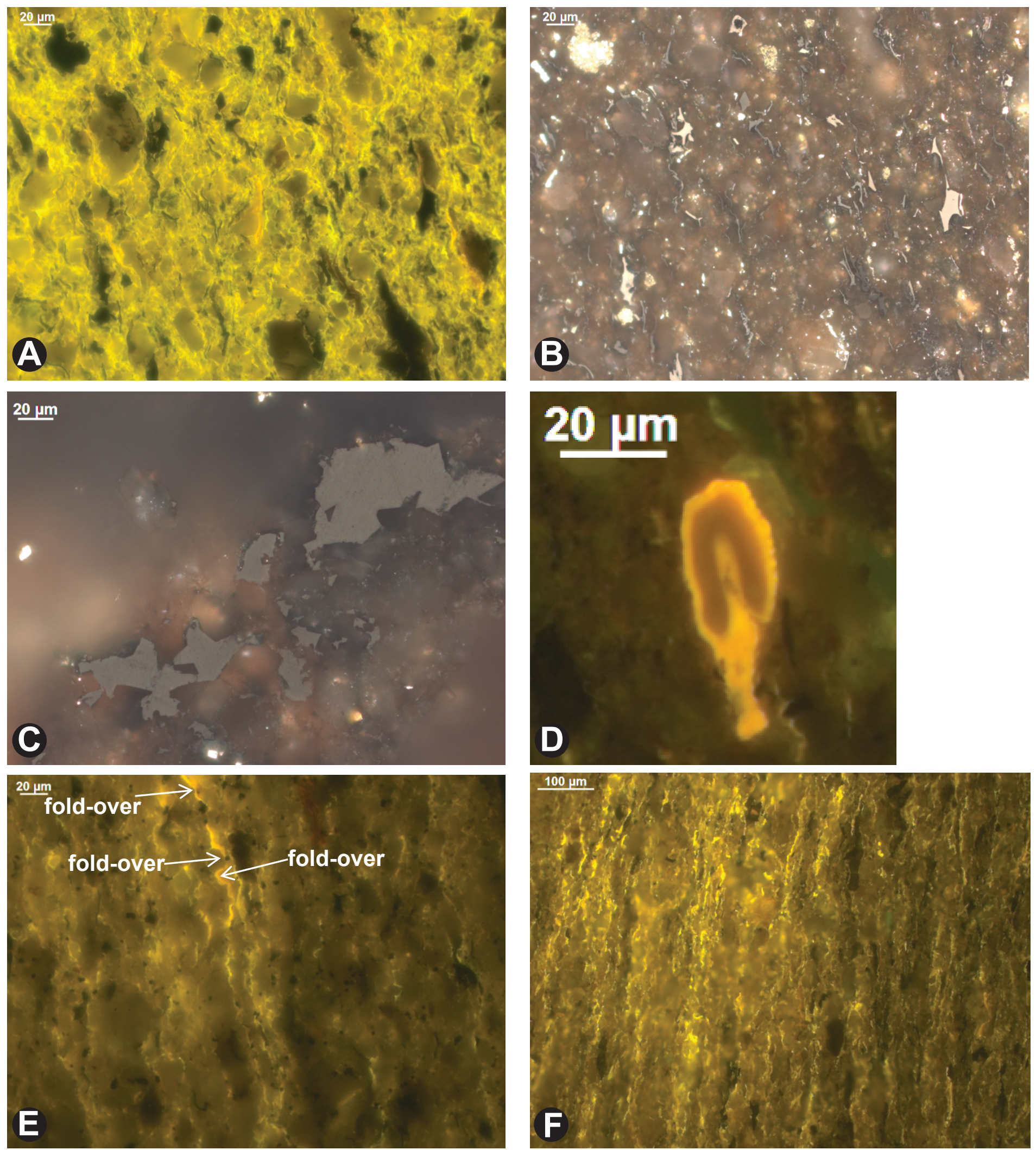

Fig. 5 

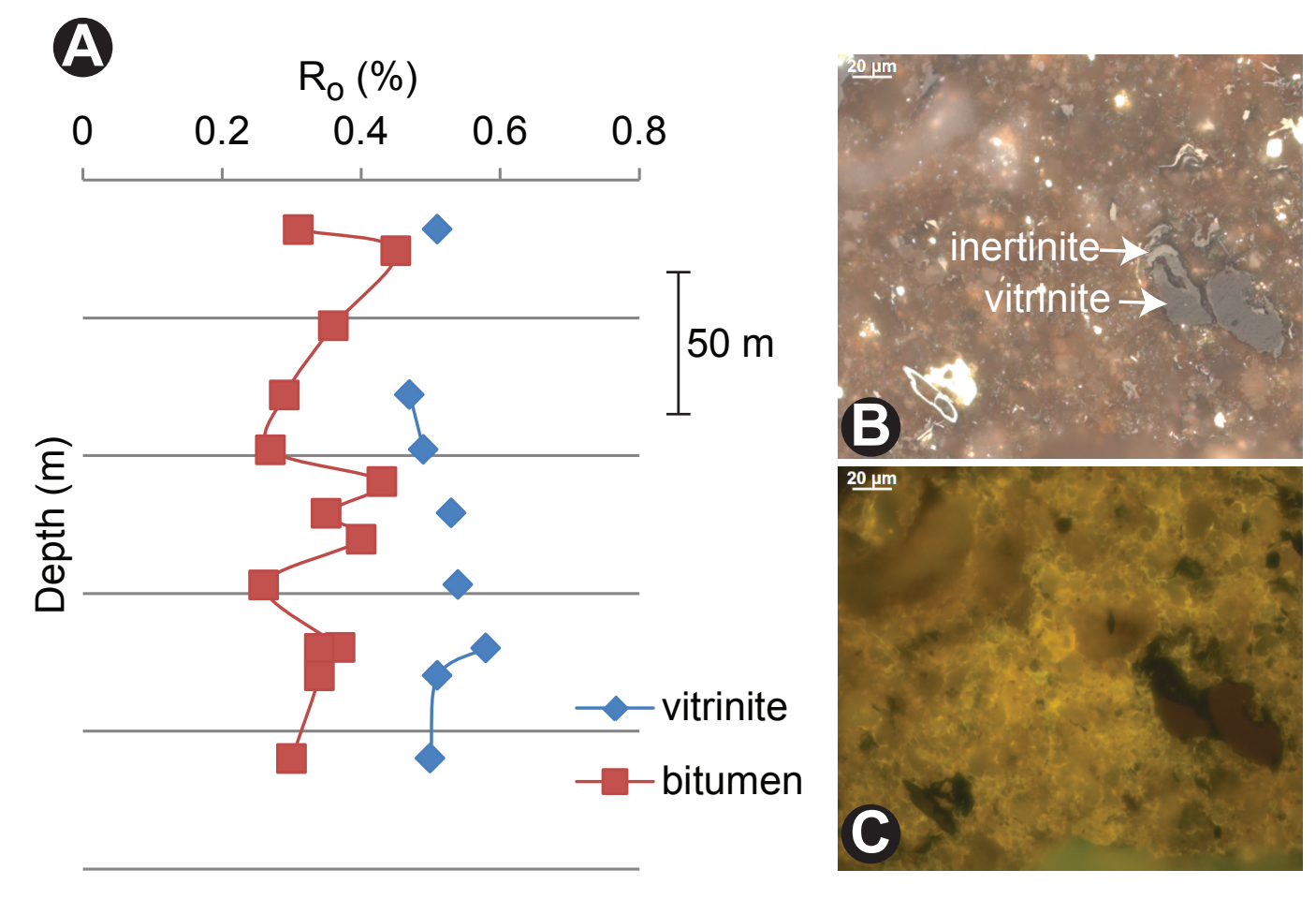

Fig. 6
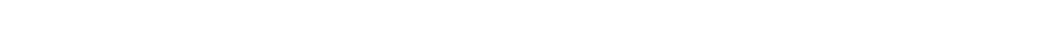

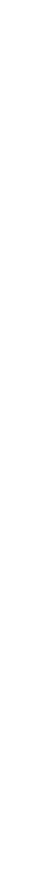

\section{$x^{2}$}



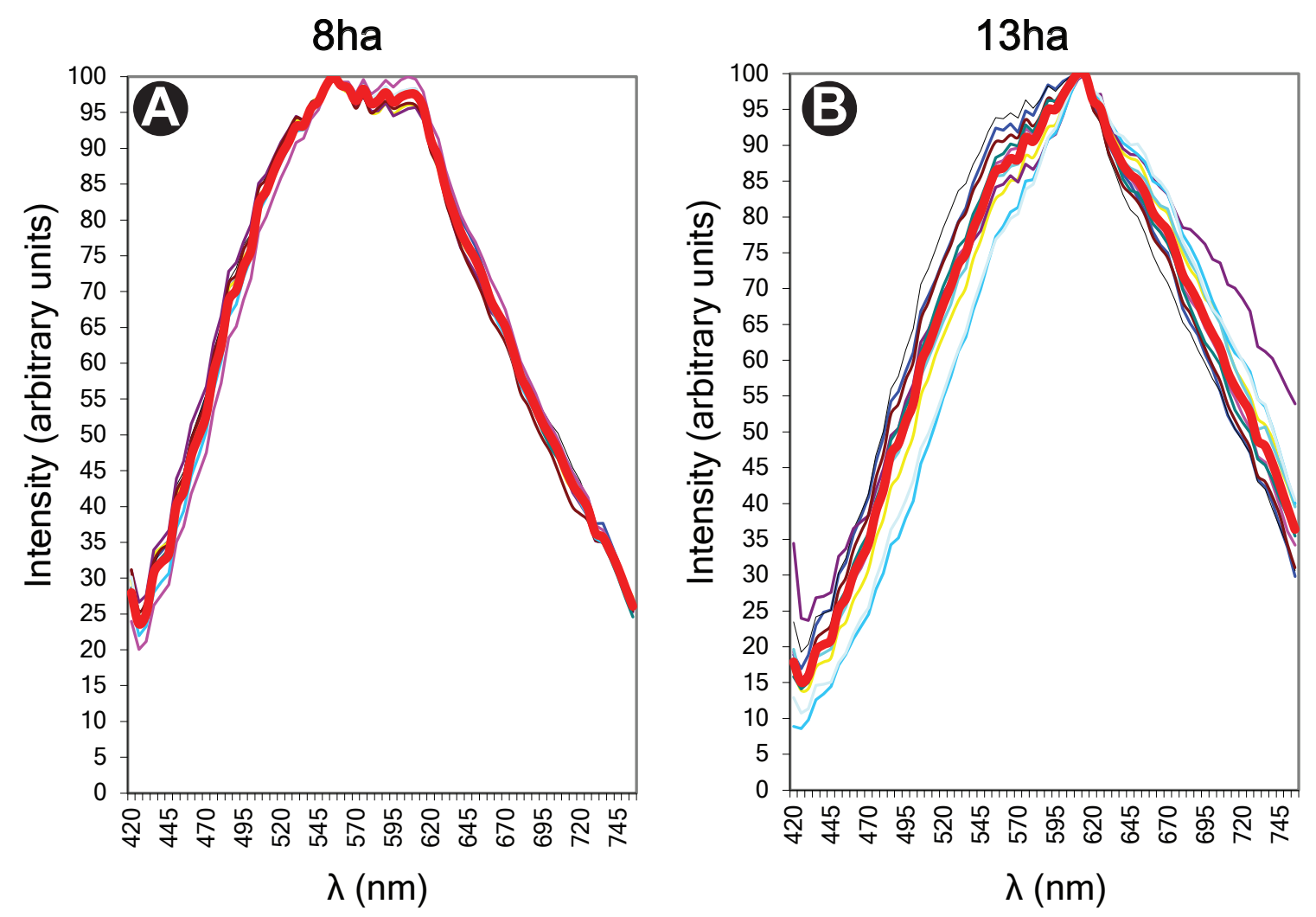

Fig. 7 


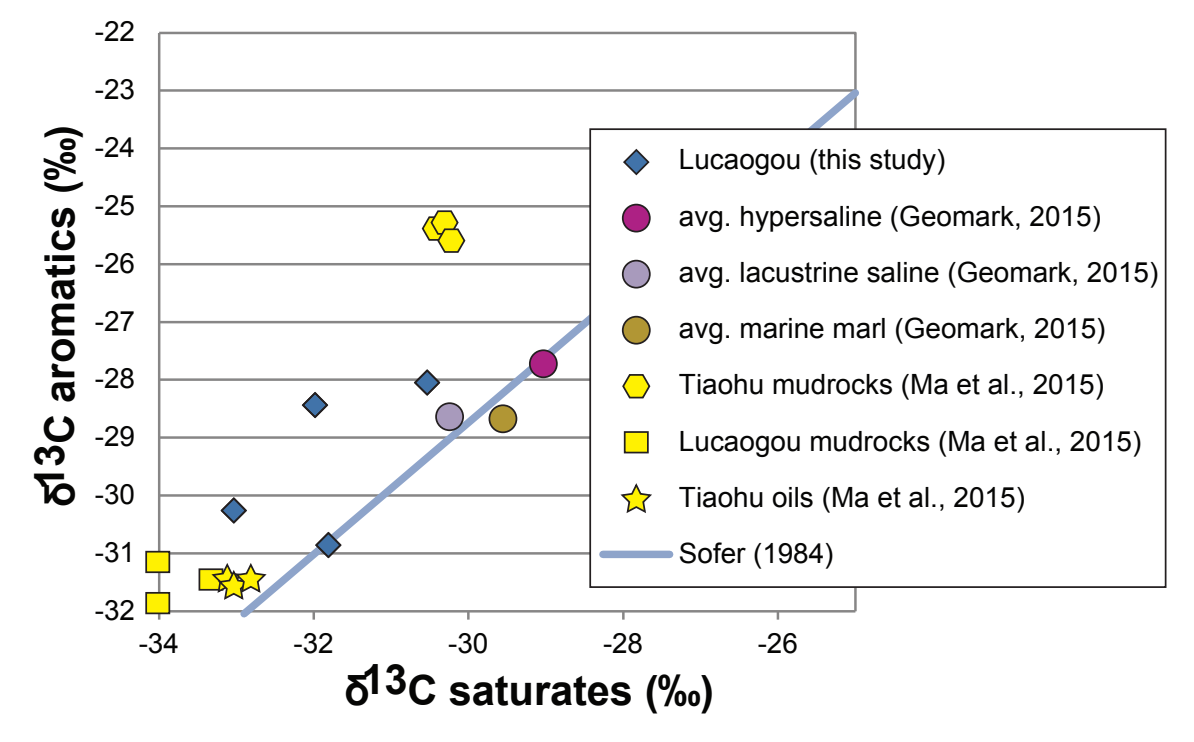

Fig. 8

Figure

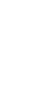

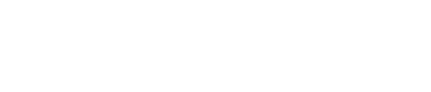


Figure
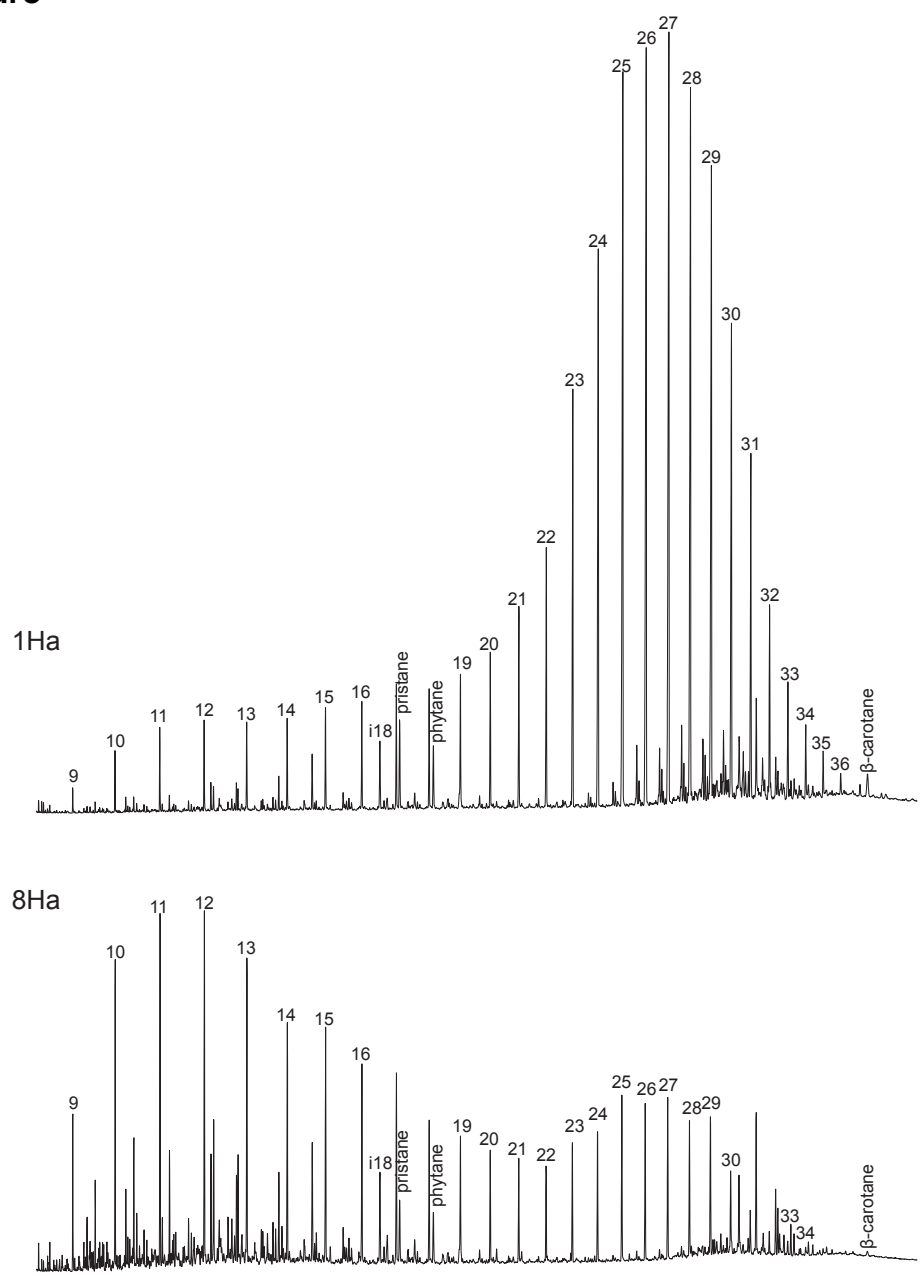

$10 \mathrm{Ha}$
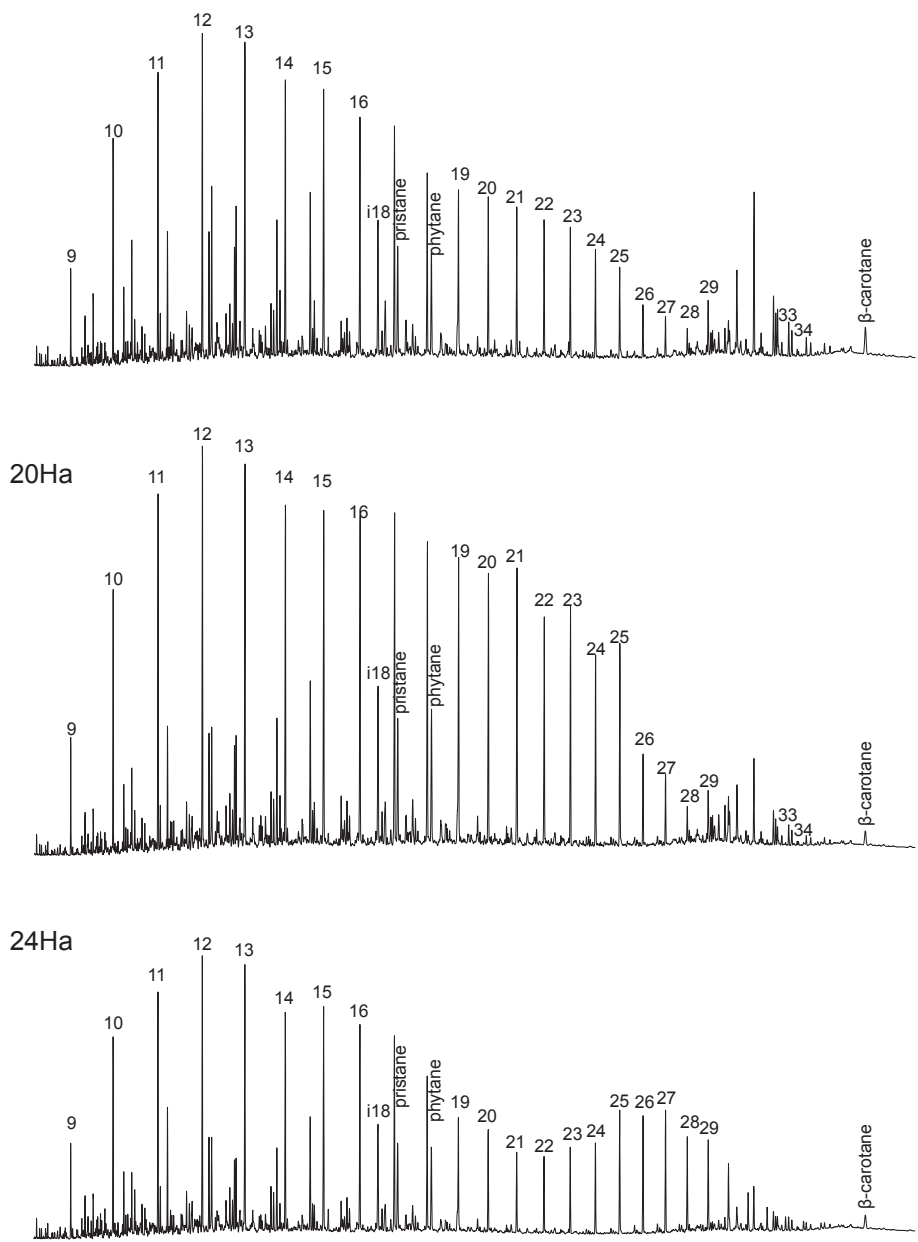

Fig. 9 


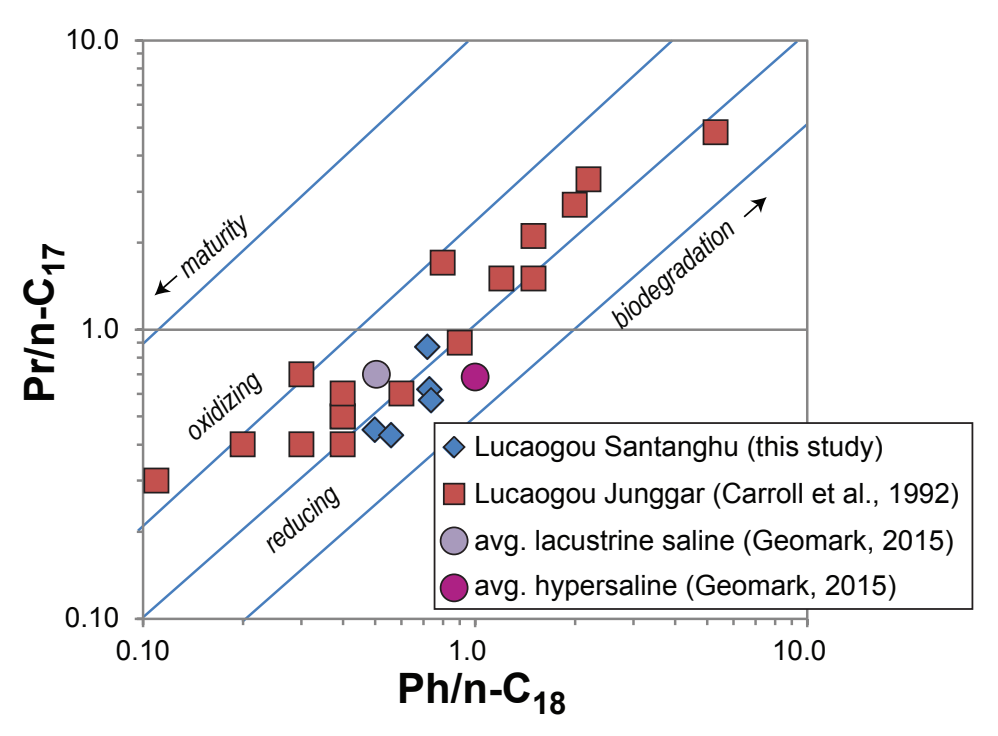

Fig. 10

Figure

$\mathrm{Ph} / \mathrm{n}-\mathrm{C}_{18}$

\section{0}

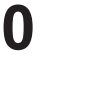

Figure

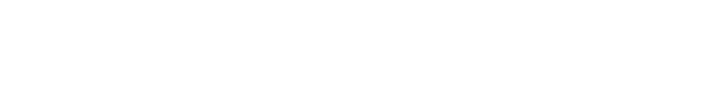

(1)

Fig. 10

.

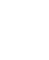

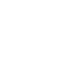

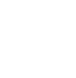

\section{(a)}



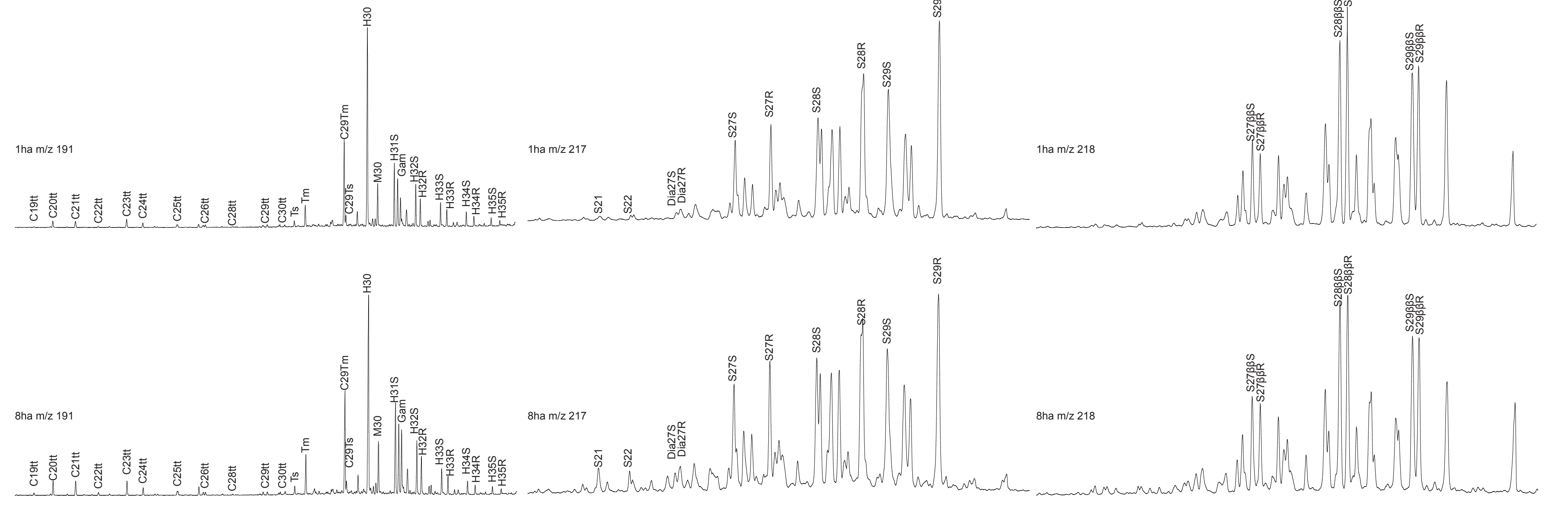

Fig. 11
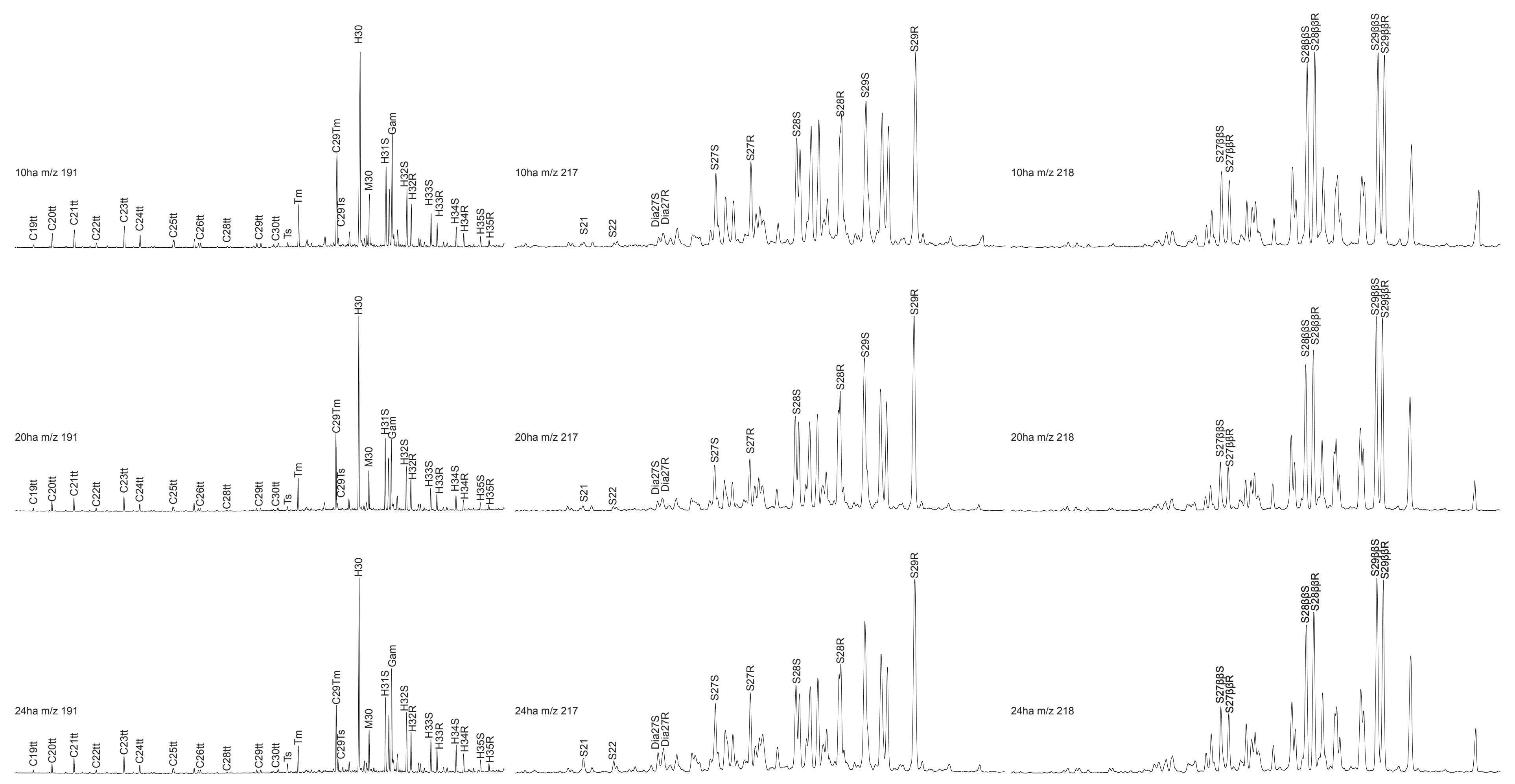


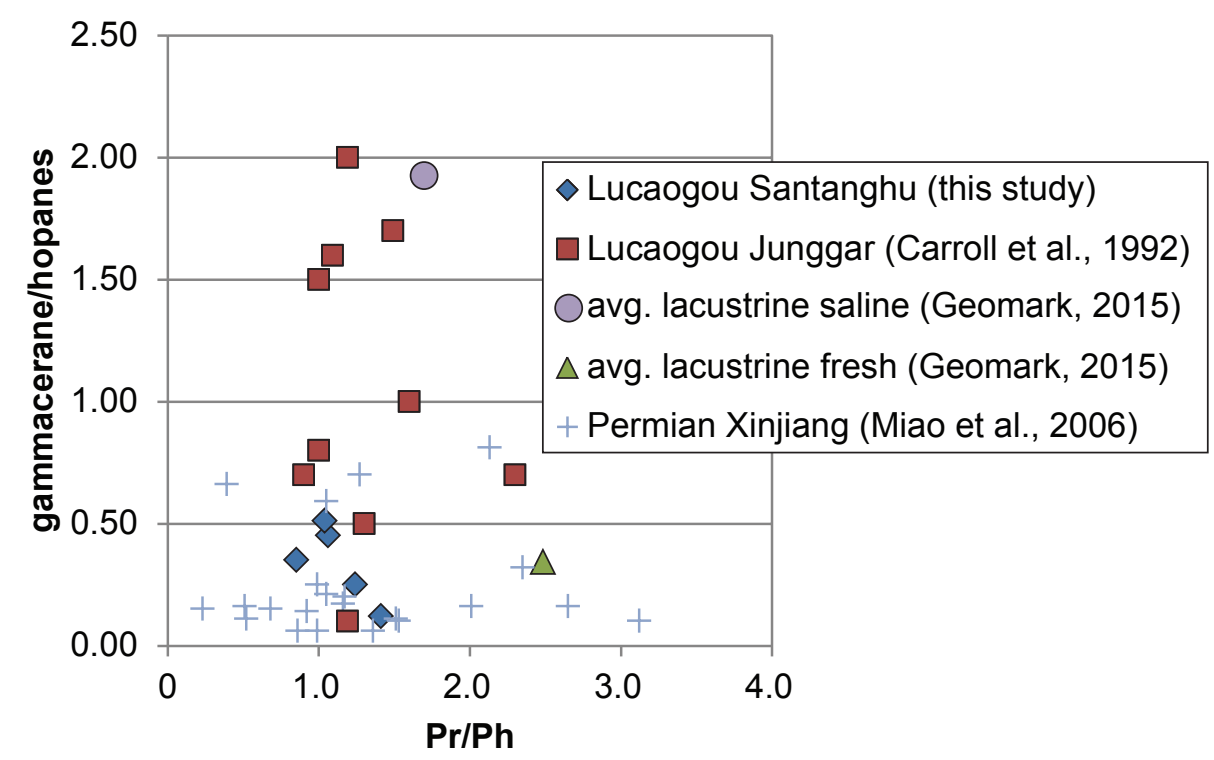

Figure

\section{Fig. 12}




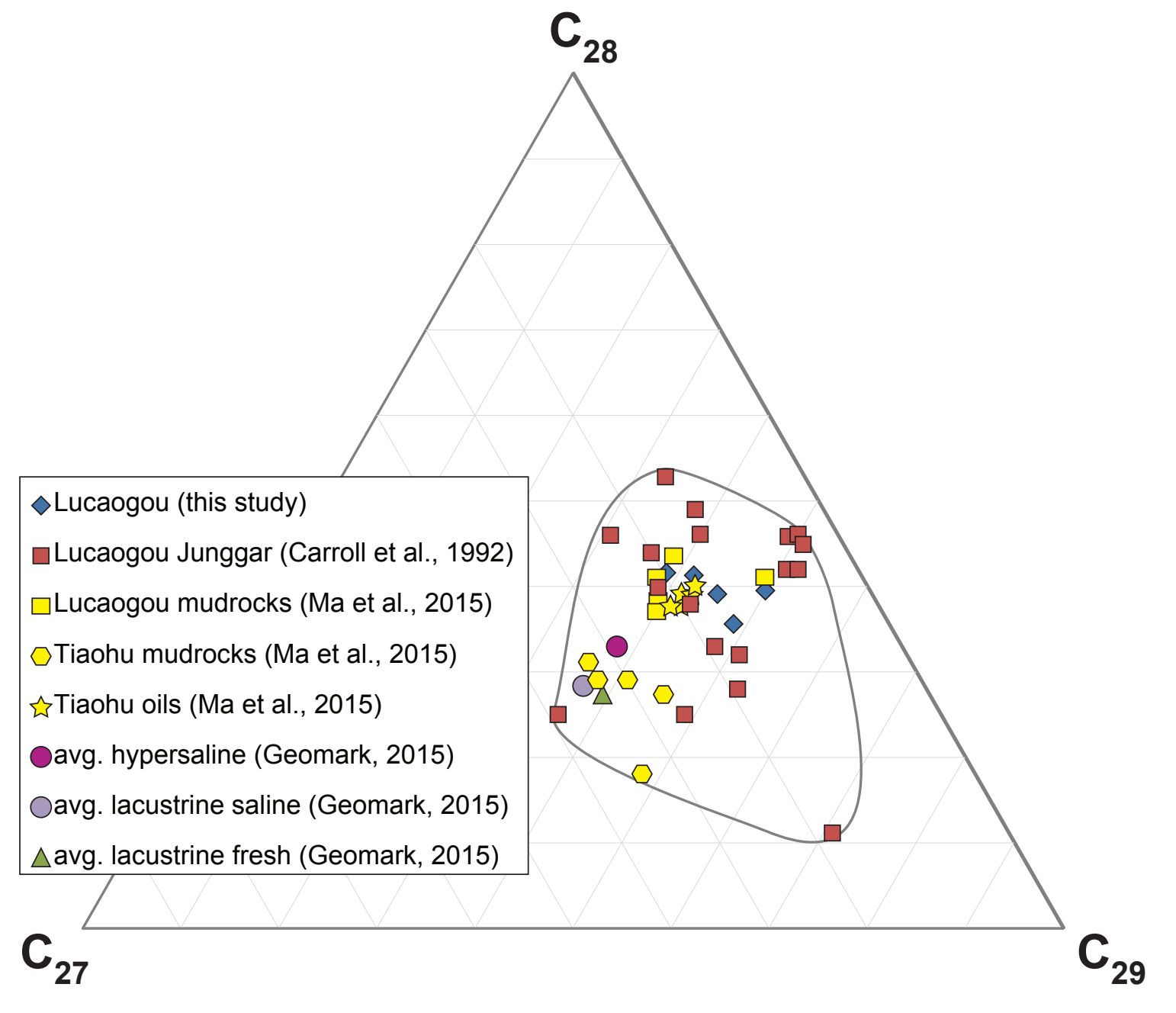

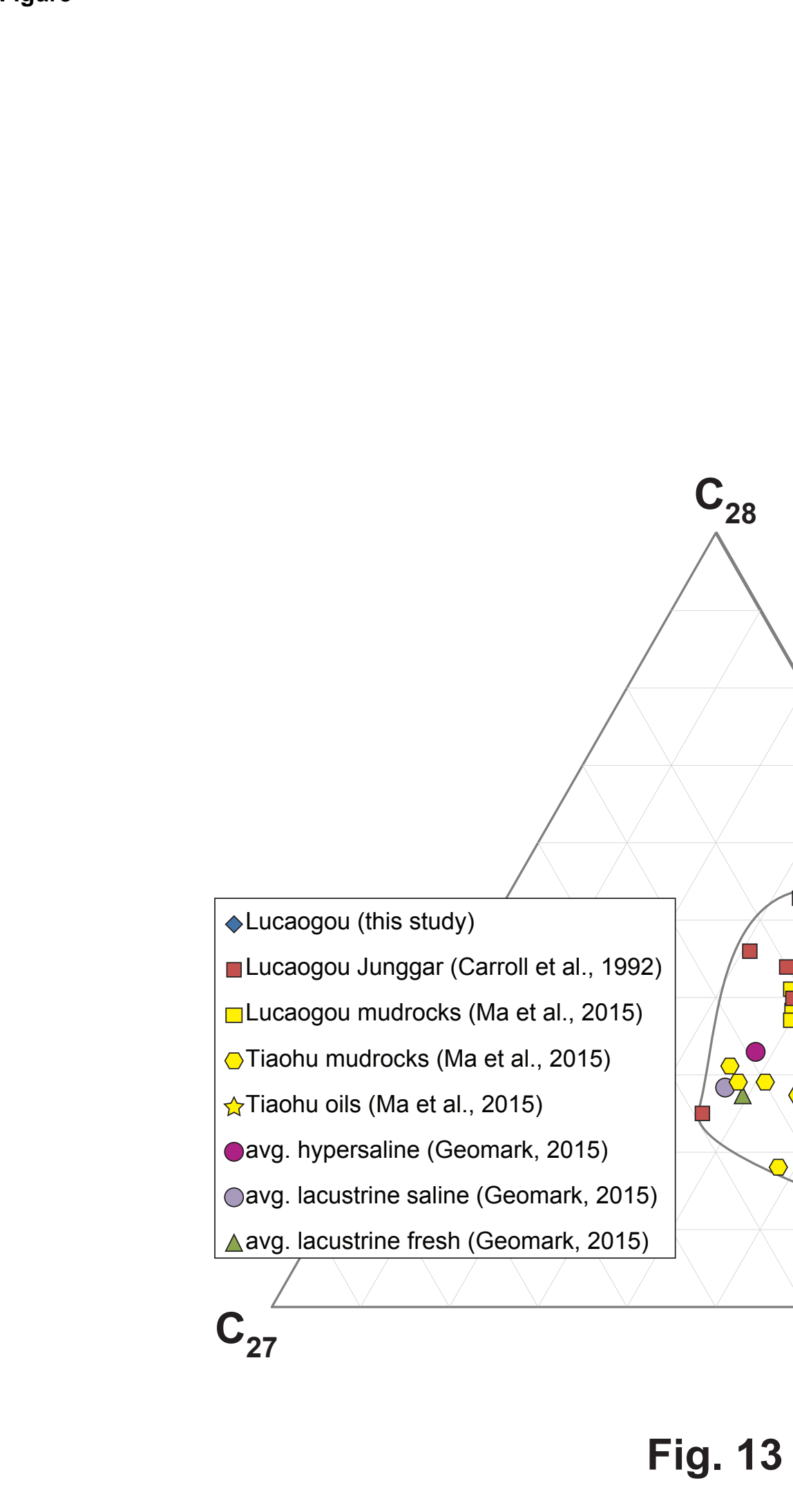

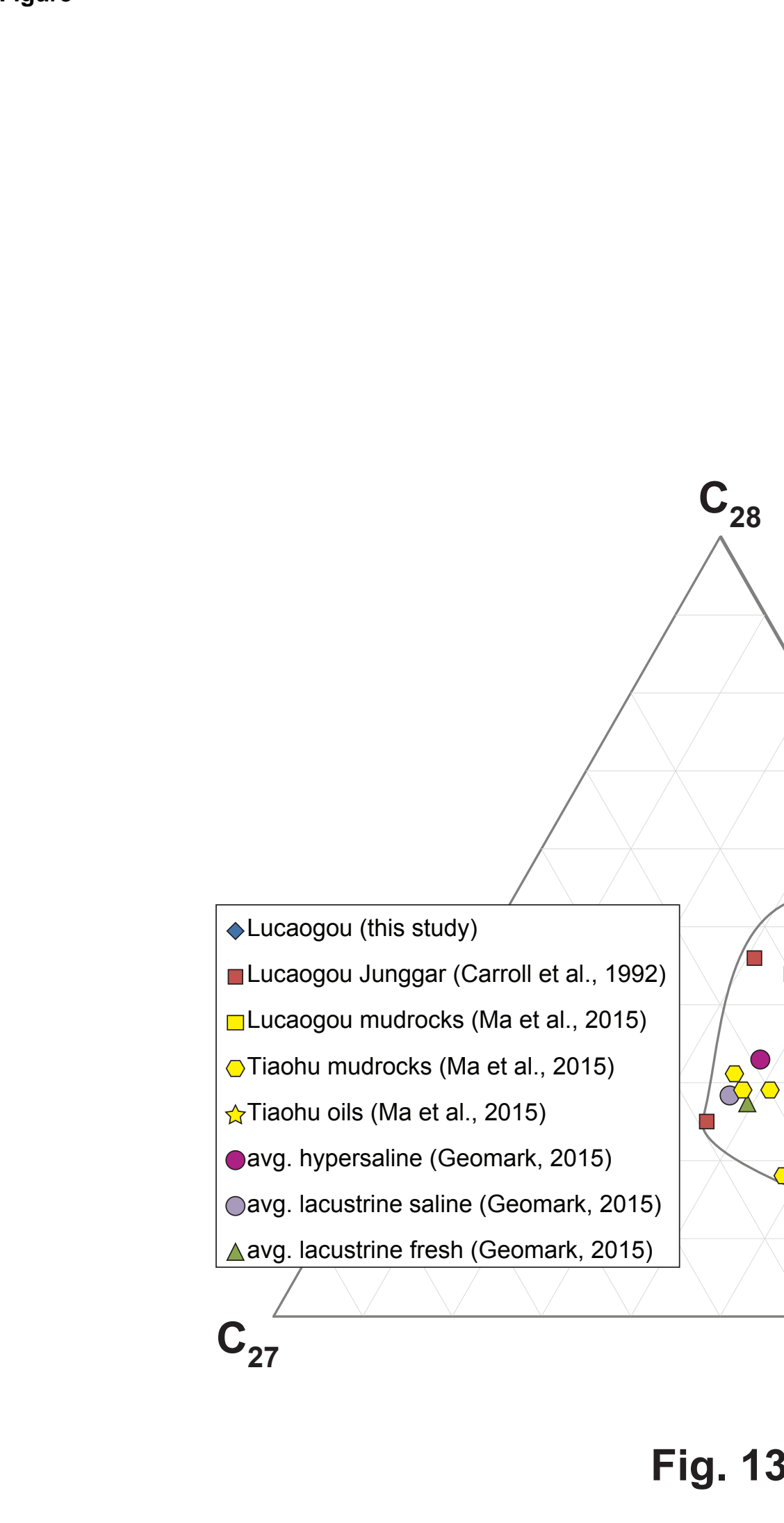

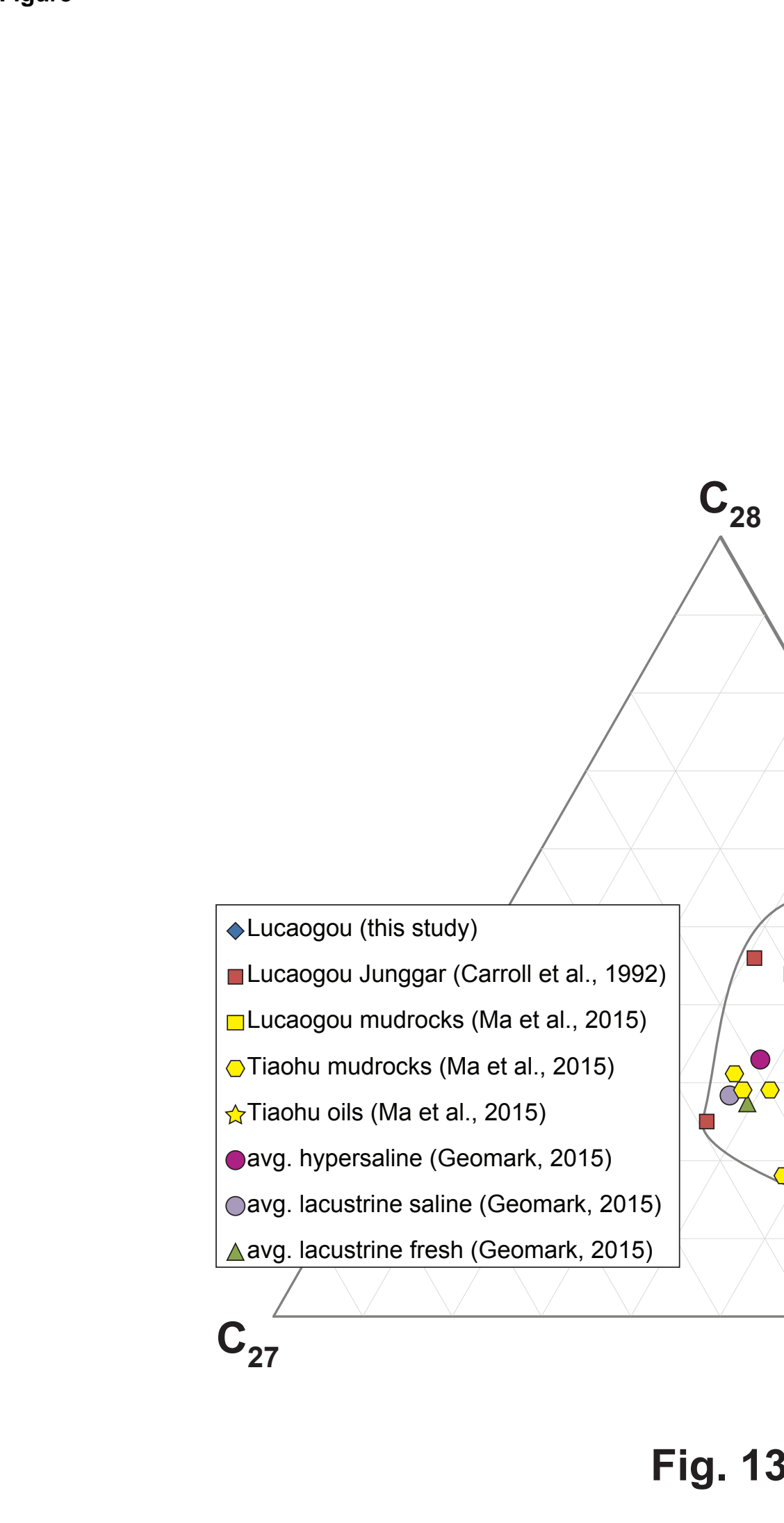

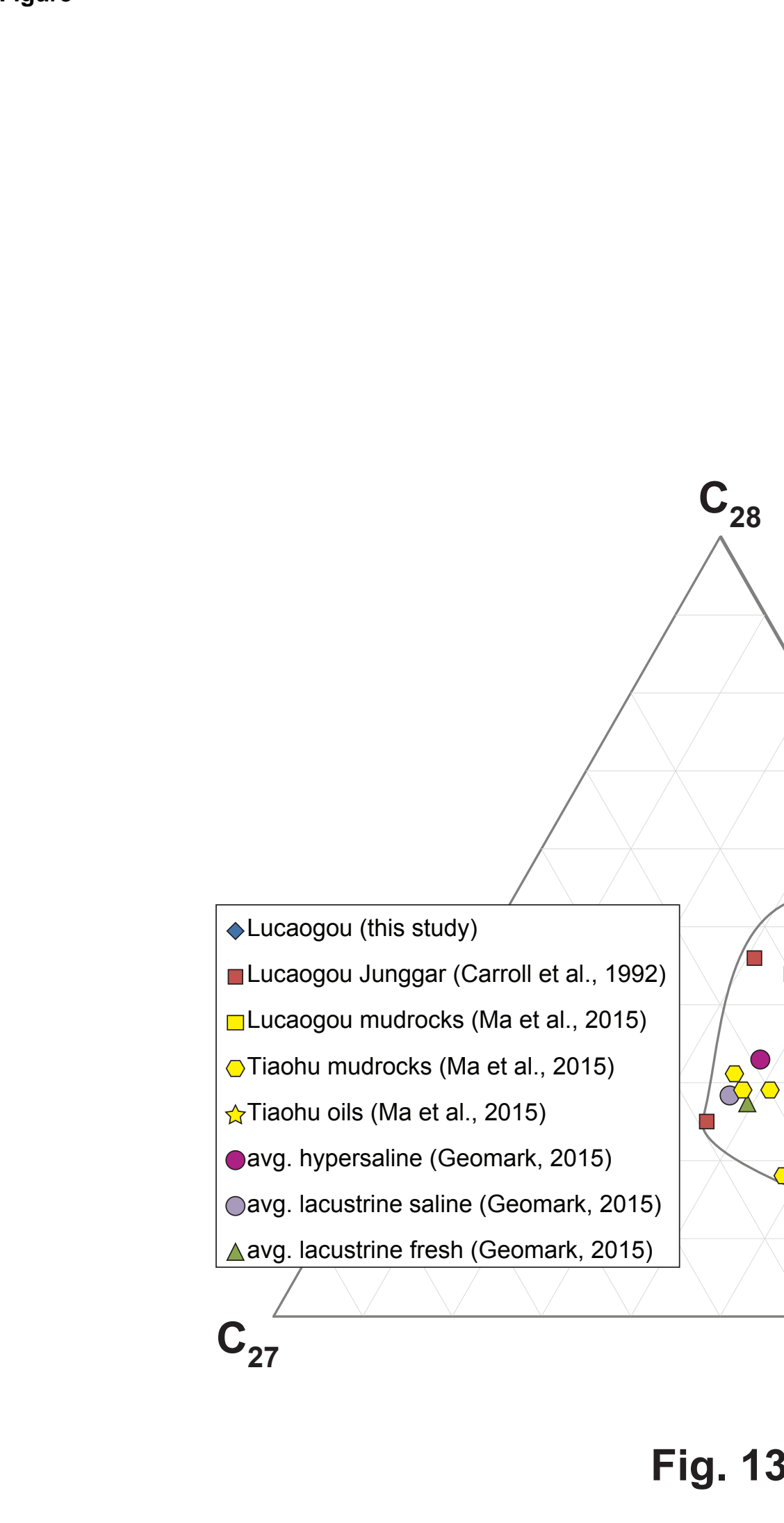

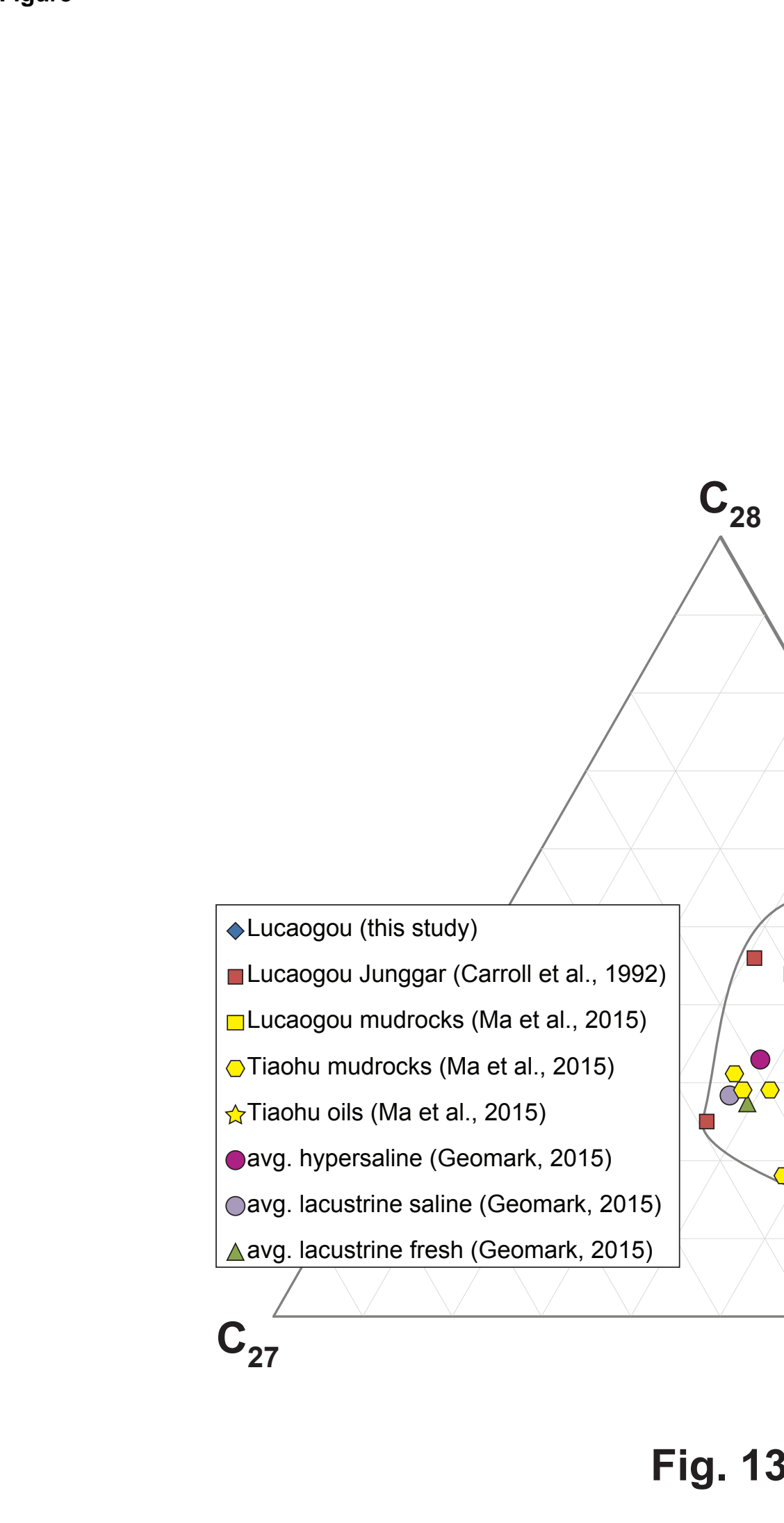

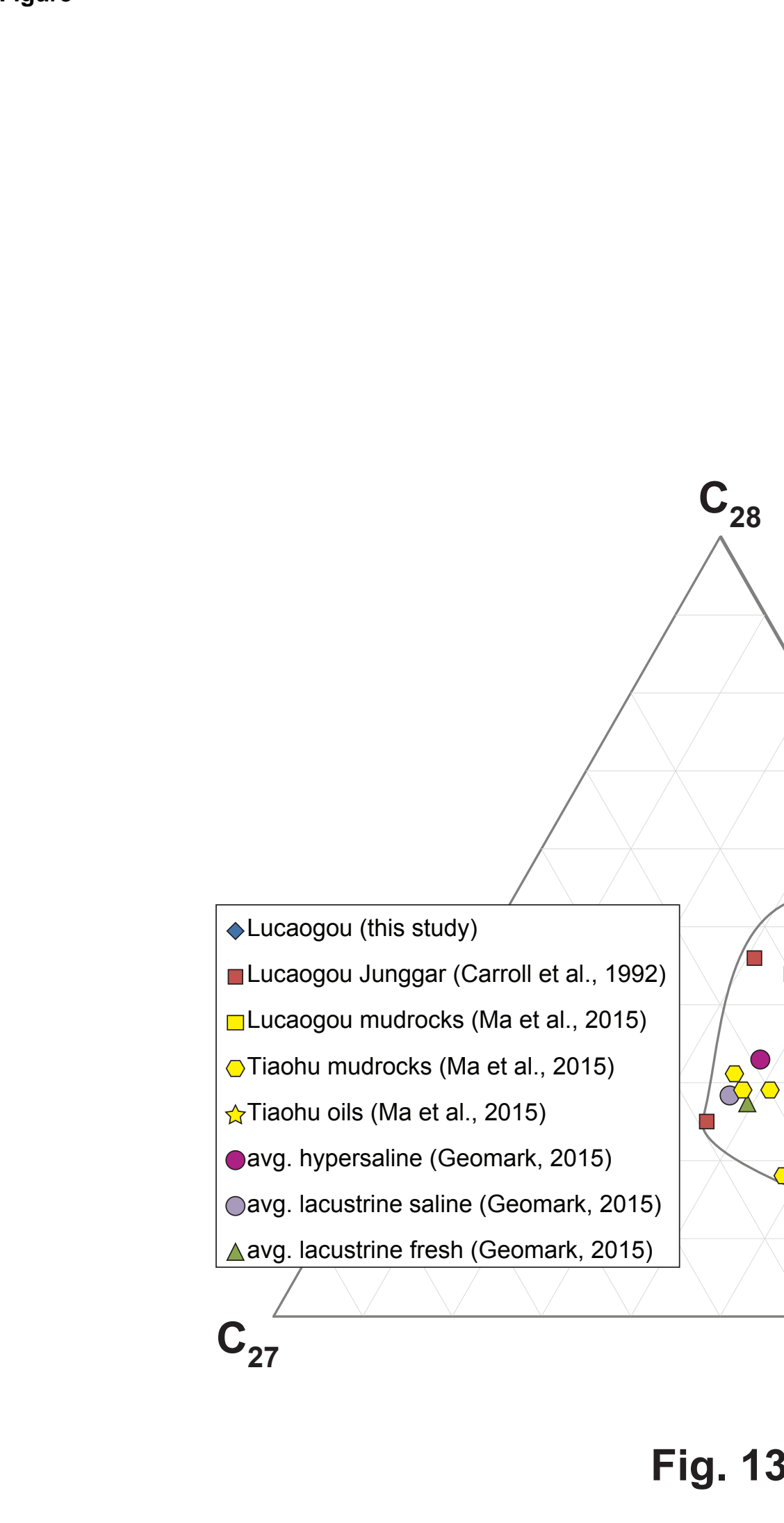

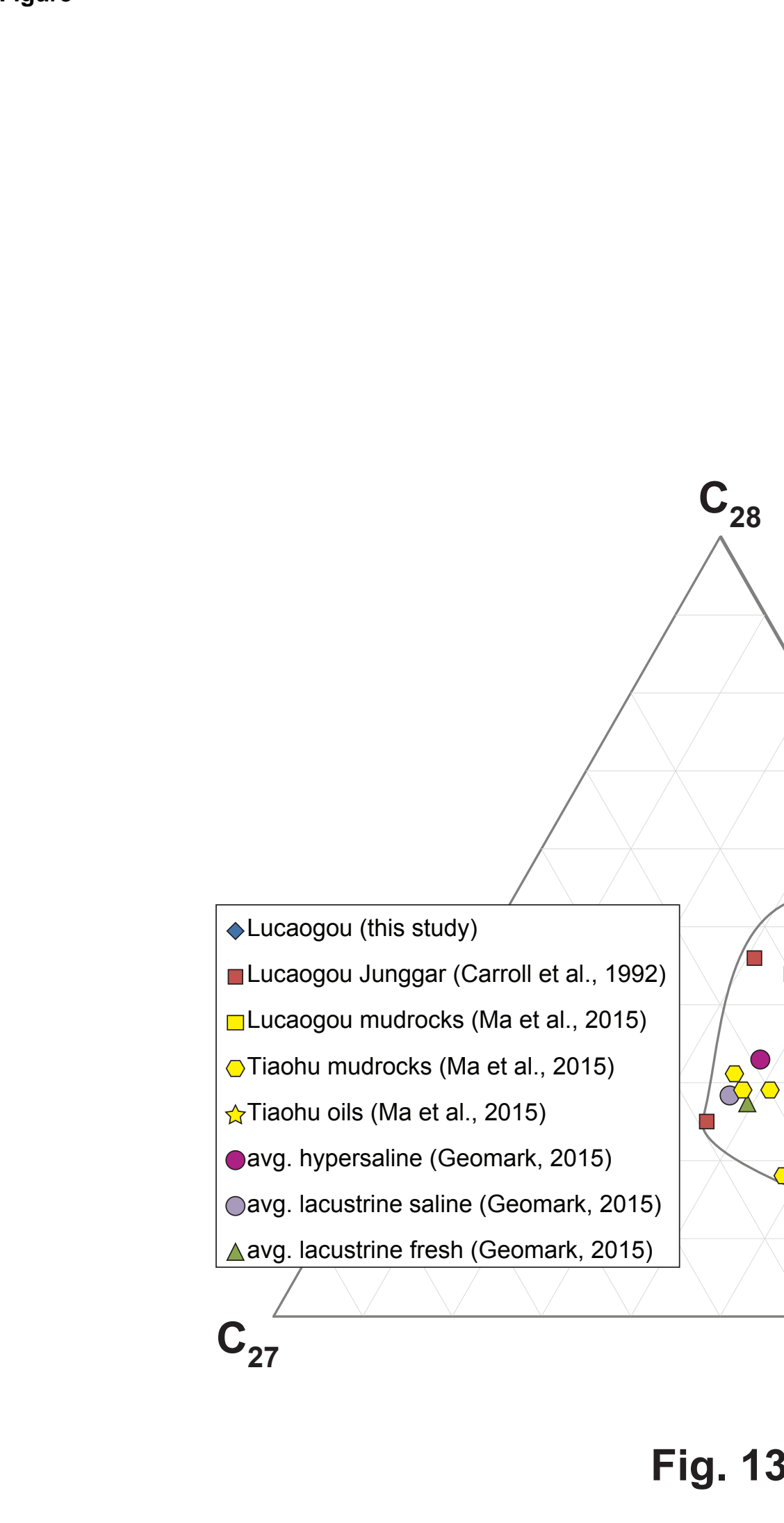

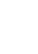

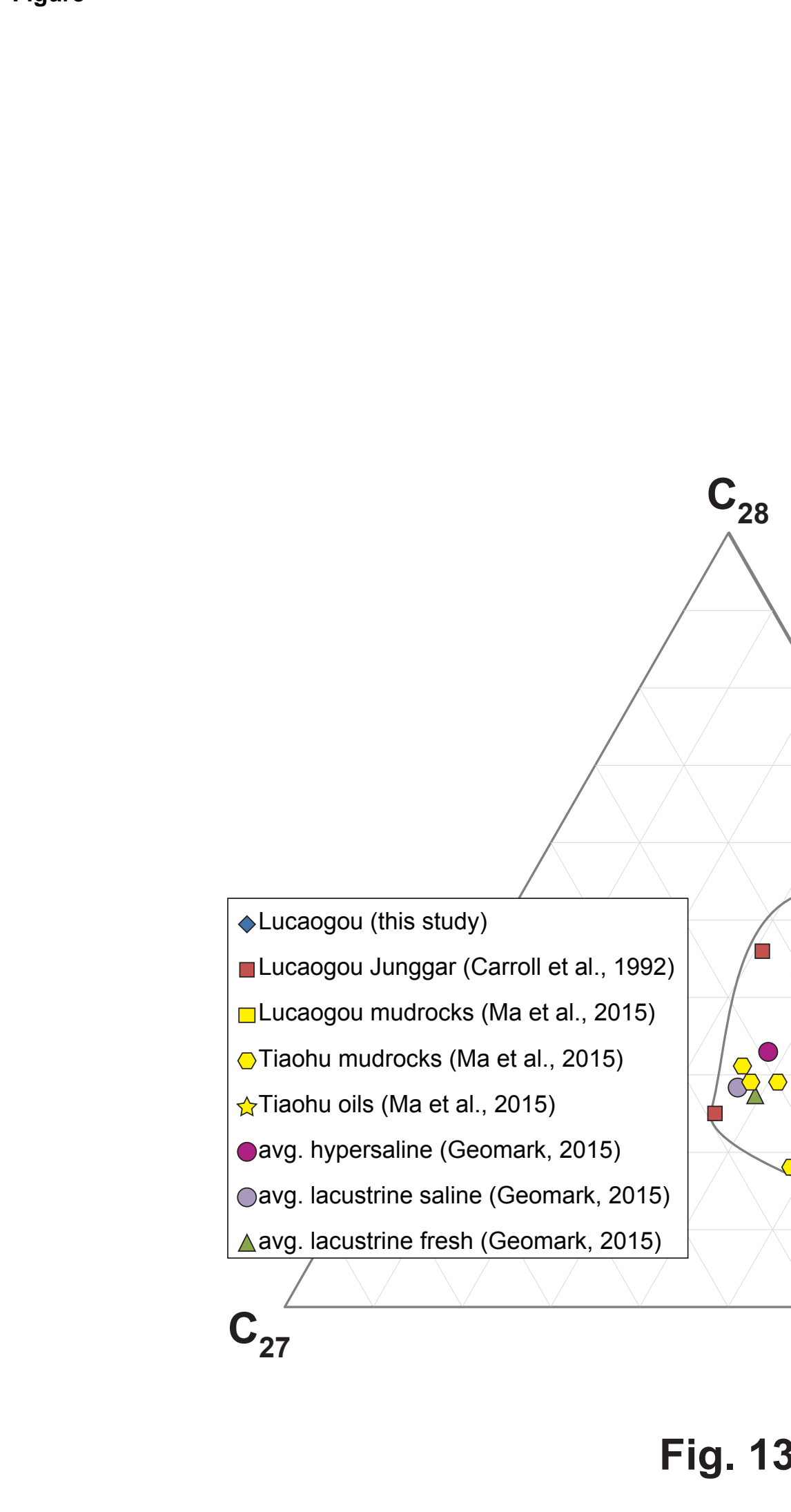






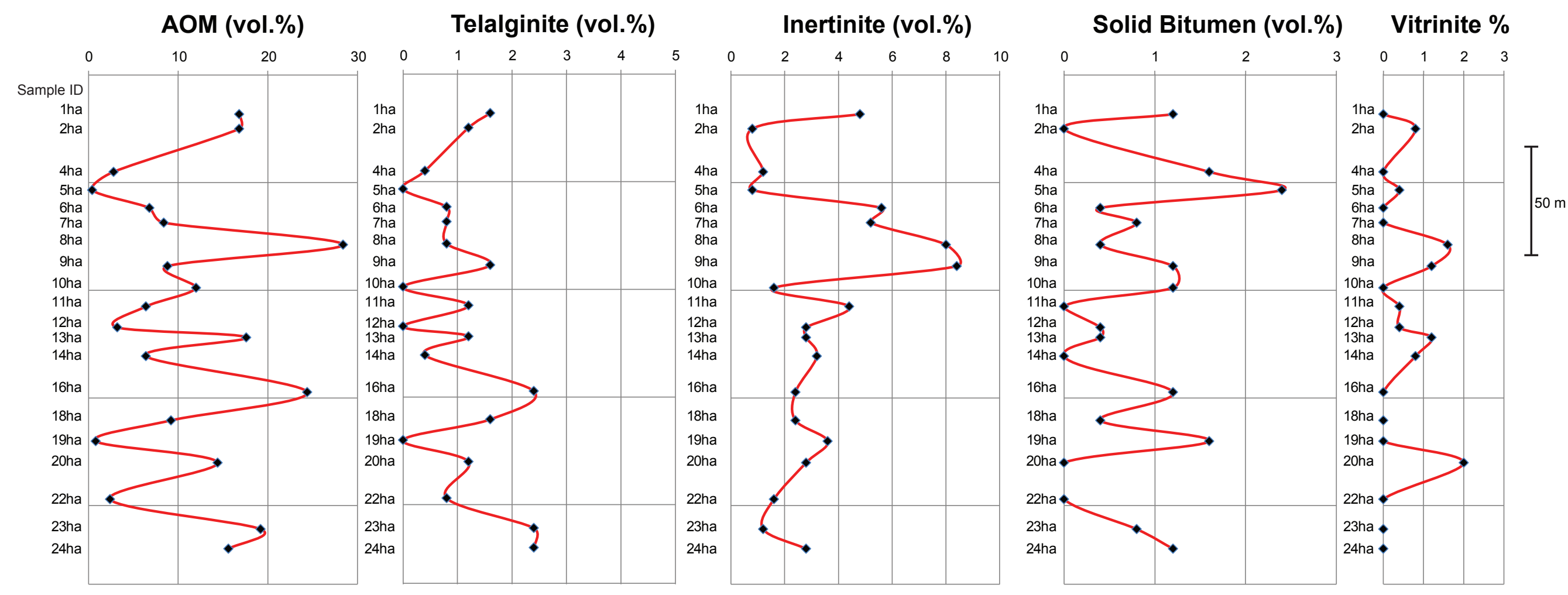

Fig. 14 

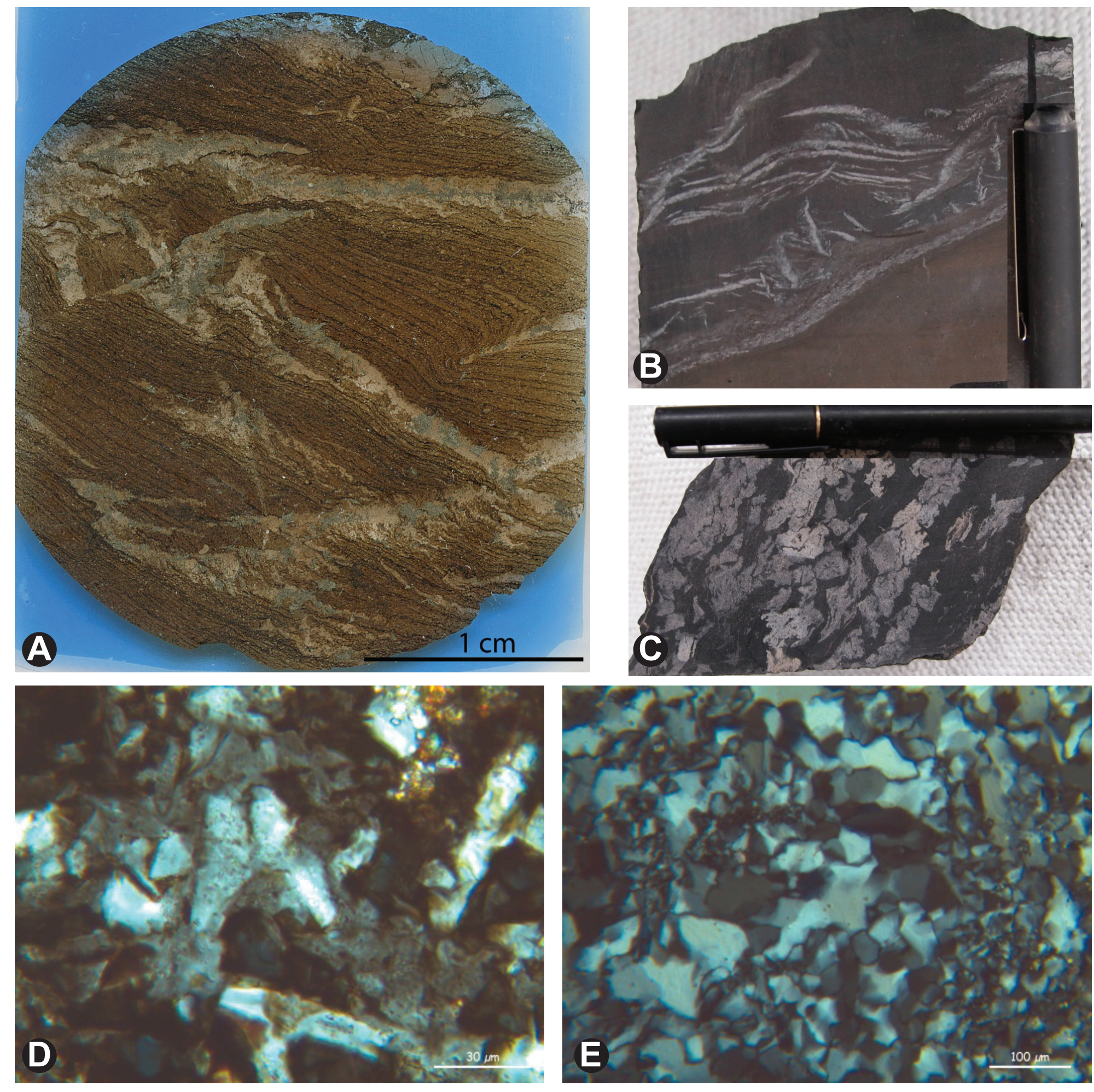

Fig. 15

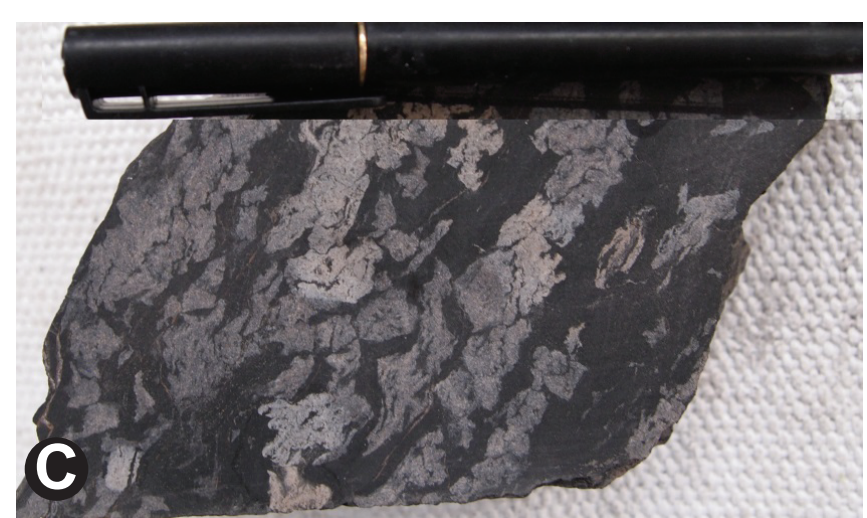




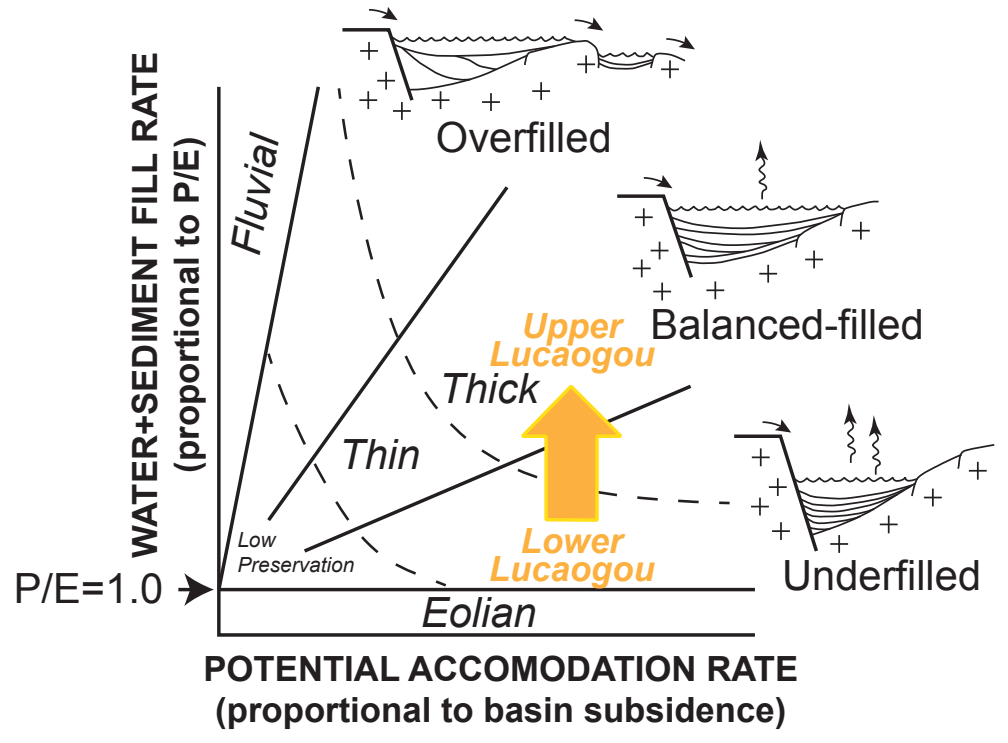

Fig. 16 
Table 1. Rock-Eval II pyrolysis and Leco direction combustion data.

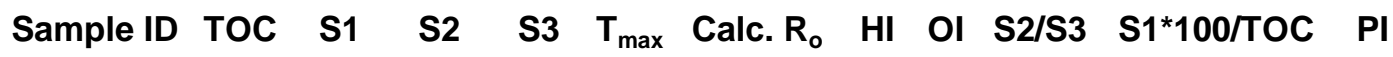

\begin{tabular}{cccccccccccc}
\hline 1ha & 5.79 & 5.02 & 29.40 & 0.73 & 436 & 0.83 & 508 & 13 & 40.27 & 86.86 & 0.15 \\
2ha & 7.45 & 2.50 & 52.30 & 0.64 & 447 & 1.04 & 702 & 9 & 81.72 & 33.62 & 0.05 \\
5ha & 3.58 & 7.35 & 25.60 & 0.47 & 441 & 0.93 & 715 & 13 & 54.47 & 205.26 & 0.22 \\
8ha & 11.35 & 3.29 & 80.26 & 0.46 & 448 & 1.06 & 707 & 4 & 174.48 & 29.00 & 0.04 \\
10ha & 5.08 & 1.62 & 33.70 & 0.37 & 447 & 1.04 & 663 & 7 & 91.08 & 31.94 & 0.05 \\
13ha & 4.98 & 0.86 & 37.59 & 0.52 & 450 & 1.10 & 755 & 10 & 72.29 & 17.19 & 0.02 \\
16ha & 4.14 & 1.43 & 27.52 & 0.50 & 448 & 1.06 & 665 & 12 & 55.04 & 34.60 & 0.05 \\
20ha & 2.81 & 0.89 & 14.39 & 0.48 & 446 & 1.02 & 512 & 17 & 29.98 & 31.52 & 0.06 \\
23ha & 4.33 & 0.73 & 29.48 & 0.48 & 449 & 1.08 & 681 & 11 & 61.42 & 16.89 & 0.02 \\
24ha & 6.25 & 0.87 & 35.92 & 0.55 & 446 & 1.02 & 575 & 9 & 65.31 & 13.97 & 0.02 \\
\hline
\end{tabular}

TOC = wt.\% total organic carbon; S1, S2 = mg hydrocarbons/g rock; S3 = $\mathrm{mg} \mathrm{CO}_{2} / \mathrm{g}$ rock;

$\mathrm{T}_{\max }$ in ${ }^{\circ} \mathrm{C}$; Calc. $\mathrm{R}_{\mathrm{o}}=\left(\mathrm{T}_{\max }{ }^{*} 0.018\right)-7.16 ; \mathrm{HI}=$ hydrogen Index $\left(\mathrm{S} 2{ }^{\star 100 / T O C}\right) ; \mathrm{OI}=$

Oxygen Index (S3*100/TOC); PI = Production Index (S1/(S1+S2)). 
Table 2. XRD mineralogy data in wt.\%.

Sample ID LOI QTZ KFLD PLAG FLD CAL SID DOL ANK CARB $\begin{gathered}\text { unresol. ILL PY OTHR } \text { clay } \\ \text { cll }\end{gathered}$

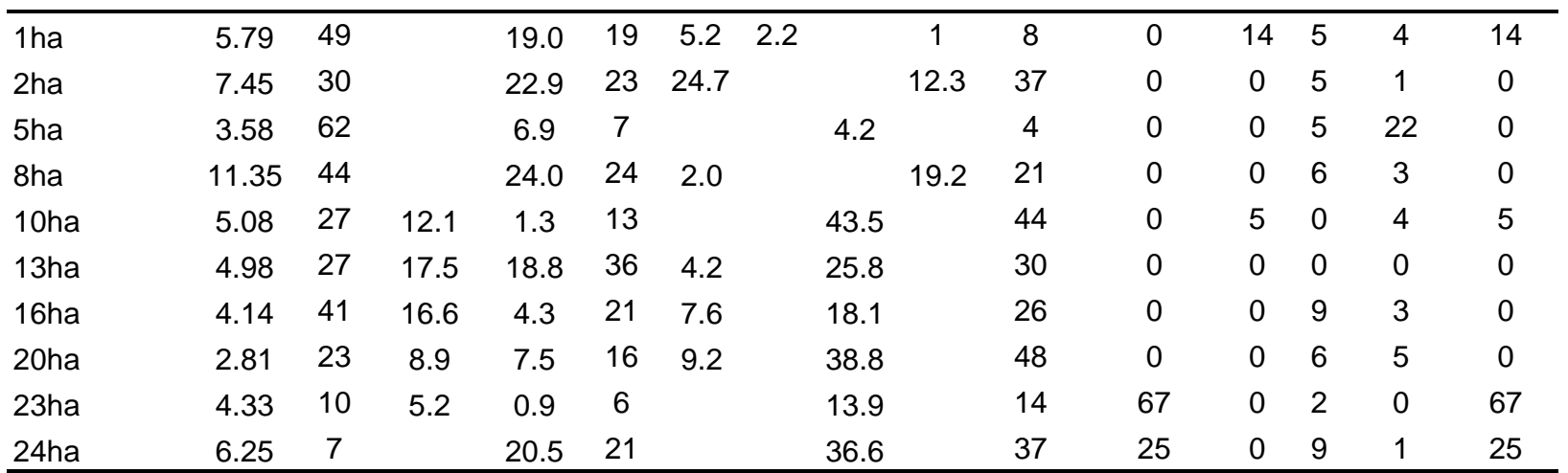

LOI, loss on ignition in wt.\%; QTZ, quartz; KFLD, potassium feldspar; PLAG, plagioclase feldspar; FLD, total feldspar; CAL, calcite; SID, siderite; DOL, dolomite; ANK, ankerite; CARB, total carbonate; ILL, illite; PY, pyrite; OTHR, trace phases; $\Sigma C L Y$, sum of clays. 
Table 3. Petrographic data in vol.\%.

Sample ID Mineral Matter AOM Telalginite Inertinite Solid Bitumen Vitrinite

\begin{tabular}{ccccccc} 
& vol.\% & vol.\% & vol.\% & vol.\% & vol.\% & vol.\% \\
\hline 1ha & 75.6 & 16.8 & 1.6 & 4.8 & 1.2 & $\operatorname{tr}$ \\
2ha & 80.4 & 16.8 & 1.2 & 0.8 & $\operatorname{tr}$ & 0.8 \\
4ha & 94.0 & 2.8 & 0.4 & 1.2 & 1.6 & $\operatorname{tr}$ \\
5ha & 96.0 & 0.4 & $\operatorname{tr}$ & 0.8 & 2.4 & 0.4 \\
6ha & 86.4 & 6.8 & 0.8 & 5.6 & 0.4 & $\operatorname{tr}$ \\
7ha & 84.8 & 8.4 & 0.8 & 5.2 & 0.8 & $\operatorname{tr}$ \\
8ha & 60.8 & 28.4 & 0.8 & 8.0 & 0.4 & 1.6 \\
9ha & 78.8 & 8.8 & 1.6 & 8.4 & 1.2 & 1.2 \\
10ha & 85.2 & 12.0 & $\operatorname{tr}$ & 1.6 & 1.2 & $\operatorname{tr}$ \\
11ha & 87.6 & 6.4 & 1.2 & 4.4 & $\operatorname{tr}$ & 0.4 \\
12ha & 93.2 & 3.2 & $\operatorname{tr}$ & 2.8 & 0.4 & 0.4 \\
13ha & 76.8 & 17.6 & 1.2 & 2.8 & 0.4 & 1.2 \\
14ha & 89.2 & 6.4 & 0.4 & 3.2 & $\operatorname{tr}$ & 0.8 \\
16ha & 69.6 & 24.4 & 2.4 & 2.4 & 1.2 & $\operatorname{tr}$ \\
18ha & 86.4 & 9.2 & 1.6 & 2.4 & 0.4 & $\operatorname{tr}$ \\
19ha & 94.0 & 0.8 & $\operatorname{tr}$ & 3.6 & 1.6 & $\operatorname{tr}$ \\
2ha & 79.6 & 14.4 & 1.2 & 2.8 & $\operatorname{tr}$ & 2.0 \\
22ha & 95.2 & 2.4 & 0.8 & 1.6 & $\operatorname{tr}$ & $\operatorname{tr}$ \\
23ha & 76.4 & 19.2 & 2.4 & 1.2 & 0.8 & $\operatorname{tr}$ \\
24ha & 77.2 & 16.4 & 2.4 & 2.8 & 1.2 & $\operatorname{tr}$ \\
\hline
\end{tabular}


Table 4. Vitrinite and solid bitumen reflectance data.

Sample ID $\% R_{o}$ no. s.d. $\% B R_{o}$ no. s.d. calc. $R_{o}$

\begin{tabular}{lccccccc}
\hline 1ha & 0.51 & 24 & 0.07 & 0.31 & 13 & 0.06 & 0.69 \\
2 5/88 & & & & 0.45 & 18 & 0.08 & \\
5ha & & & & 0.36 & 25 & 0.05 & 0.78 \\
8ha & 0.47 & 25 & 0.06 & 0.29 & 14 & 0.04 & 0.90 \\
10ha & 0.49 & 20 & 0.07 & 0.27 & 2 & 0.01 & 0.89 \\
8 95/95 & & & & 0.43 & 34 & 0.12 & \\
13ha & 0.53 & 18 & 0.04 & 0.35 & 16 & 0.08 & 0.94 \\
10 48/88 & & & & 0.40 & 12 & 0.08 & \\
16ha & 0.54 & 23 & 0.06 & 0.26 & 8 & 0.05 & 0.90 \\
14 28/30 & & & & 0.37 & 11 & 0.09 & \\
19ha & 0.58 & 13 & 0.07 & 0.34 & 8 & 0.09 & \\
20ha & 0.51 & 29 & 0.07 & 0.34 & 5 & 0.04 & 0.87 \\
23ha & 0.50 & 10 & 0.05 & 0.30 & 4 & 0.03 & 0.92 \\
\hline
\end{tabular}

Abbreviations: $\% \mathrm{R}_{0}$, vitrinite reflectance; no., number

of measurements; s.d., standard deviation; $\% \mathrm{BR}_{\mathrm{o}}$, solid bitumen reflectance. 
Table 5. Spectral data from Lucaogou samples.

\begin{tabular}{llllll} 
Sample ID & maceral & $\boldsymbol{\lambda}_{\max }(\mathbf{n m})$ & no. & s.d. & Calc. $\mathbf{R}_{\mathbf{o}}$ \\
\hline 1ha & telalginite & 615 & 10 & 2.1 & 0.67 \\
8ha & AOM & 555 & 9 & 16.7 & 0.50 \\
10ha & AOM & 615 & 6 & 1.8 & 0.67 \\
13ha & telalginite & 610 & 10 & 2.6 & 0.66 \\
16ha & AOM & 615 & 10 & 1.6 & 0.67 \\
23ha & AOM & 610 & 10 & 1.6 & 0.66 \\
\hline
\end{tabular}


Table 6. $\delta^{13} \mathrm{C}$ isotope data.

\begin{tabular}{lcccccc} 
Sample ID & $\begin{array}{c}\delta^{13} \mathrm{C} \text { Saturate } \\
(\%)\end{array}$ & no. & s.d. & $\begin{array}{c}\delta^{13} \mathrm{C} \text { Aromatic } \\
(\%)\end{array}$ & no. & s.d. \\
\hline $1 \mathrm{Ha}$ & n.r. & 4 & n.a. & -30.97 & 4 & 0.07 \\
$8 \mathrm{Ha}$ & -31.81 & 4 & 0.19 & -30.86 & 4 & 0.08 \\
$10 \mathrm{Ha}$ & -33.03 & 4 & 0.16 & -30.26 & 4 & 0.08 \\
$20 \mathrm{Ha}$ & -31.98 & 4 & 0.19 & -28.44 & 4 & 0.06 \\
$24 \mathrm{Ha}$ & -30.53 & 4 & 0.18 & -28.05 & 4 & 0.02 \\
\hline
\end{tabular}

n.r., not reproducible; no., number of analyses; s.d., standard deviation; n.a., not applicable, reported relative to PDB. 
Table 7. SARA fractionation data.

\begin{tabular}{lccccccc} 
Sample ID & $\begin{array}{c}\text { Bitumen } \\
\text { (ppm) }\end{array}$ & Sat (\%) & Aro (\%) & NSO (\%) & Asph (\%) & \% Recovery & Sat/Aro Ratio \\
\hline $1 \mathrm{Ha}$ & 21766 & 74.6 & 12.3 & 10.2 & 2.2 & 99.3 & 6.1 \\
$8 \mathrm{Ha}$ & 5333 & 42.2 & 21.0 & 15.8 & 7.5 & 86.5 & 2.0 \\
$10 \mathrm{Ha}$ & 4669 & 31.1 & 26.2 & 28.8 & 10.4 & 96.4 & 1.2 \\
$20 \mathrm{Ha}$ & 2971 & 37.1 & 17.7 & 24.4 & 11.0 & 90.1 & 2.1 \\
$24 \mathrm{Ha}$ & 3181 & 36.7 & 19.6 & 21.7 & 11.5 & 89.5 & 1.9 \\
\hline
\end{tabular}

All fractions are for $\mathrm{C}_{15}+$. 
Table 8. Saturate gas chromatography and gas chromatography-mass spectrometry data.

\begin{tabular}{|c|c|c|c|c|c|c|c|c|}
\hline Sample ID & $\mathrm{Pr} / \mathrm{Ph}$ & $\mathrm{Pr} / \mathrm{C}_{17}$ & $\mathrm{Ph} / \mathrm{C}_{18}$ & $n \mathrm{C}_{18} /\left(n \mathrm{C}_{18}+n \mathrm{C}_{19}\right)$ & $n \mathrm{C}_{17} /\left(n \mathrm{C}_{17}+n \mathrm{C}_{29}\right)$ & Iso/n-alkanes & CPI (Hunt) & $\begin{array}{l}\text { CPI (Marzi, } \\
\text { for sat fr) }\end{array}$ \\
\hline $1 \mathrm{Ha}$ & 1.41 & 0.87 & 0.72 & 0.43 & 0.12 & 0.05 & 1.07 & 1.05 \\
\hline $8 \mathrm{Ha}$ & 1.24 & 0.45 & 0.5 & 0.49 & 0.55 & 0.17 & 1.06 & 1.10 \\
\hline $10 \mathrm{Ha}$ & 1.06 & 0.62 & 0.73 & 0.48 & 0.79 & 0.29 & n.c. & 1.20 \\
\hline $20 \mathrm{Ha}$ & 0.85 & 0.43 & 0.56 & 0.48 & 0.82 & 0.20 & 1.24 & 1.35 \\
\hline $24 \mathrm{Ha}$ & 1.04 & 0.57 & 0.74 & 0.52 & 0.67 & 0.23 & 1.04 & 1.09 \\
\hline
\end{tabular}

n.c., not calculated

\begin{tabular}{|c|c|c|c|c|c|c|c|}
\hline Sample ID & $\mathrm{Ga} / \mathrm{Hop}$ & $\% \mathrm{C}_{27} \alpha \alpha \alpha \mathrm{R}$ & $\% \mathrm{C}_{28} \alpha \alpha \alpha \mathrm{R}$ & $\% \mathrm{C}_{29} \alpha \alpha \alpha \mathrm{R}$ & $S /(S+R)(C 29 \alpha \alpha \alpha)$ & $\begin{array}{c}\beta \beta S /(\beta \beta S+\alpha \alpha R) \\
(C 29)\end{array}$ & $\begin{array}{l}\text { H32 S/(R+S) } \\
\text { Homohopane }\end{array}$ \\
\hline $1 \mathrm{Ha}$ & 0.12 & 17.0 & 41.3 & 41.7 & 0.44 & 0.25 & 0.60 \\
\hline $8 \mathrm{Ha}$ & 0.25 & 19.8 & 41.6 & 38.7 & 0.46 & 0.29 & 0.59 \\
\hline $10 \mathrm{Ha}$ & 0.45 & 15.7 & 39.1 & 45.2 & 0.46 & 0.35 & 0.58 \\
\hline $20 \mathrm{Ha}$ & 0.35 & 10.6 & 39.5 & 49.9 & 0.44 & 0.30 & 0.58 \\
\hline $24 \mathrm{Ha}$ & 0.51 & 15.9 & 35.6 & 48.6 & 0.47 & 0.31 & 0.59 \\
\hline
\end{tabular}

Ga/Hop, Ga/C30 17a(H)-hopane 
Table 9. Abbreviations for labeled biomarker compounds in Figure 11.

\begin{tabular}{|c|c|c|}
\hline $\mathrm{m} / \mathrm{z}$ & Abbreviation & Compound \\
\hline \multirow[t]{11}{*}{191} & C19tt-C30tt & 19C-30C tricyclic terpanes \\
\hline & Ts & $18 \alpha(\mathrm{H})$-trisnorhopane \\
\hline & $\mathrm{Tm}$ & $17 \alpha(H)$-trisnorhopane \\
\hline & C29Tm & C29 17a(H)21ß(H)-norhopane \\
\hline & C29Ts & C29 18a(H)-norneohopane \\
\hline & H30 & C30 17a(H)-hopane \\
\hline & M30 & C30 moretane \\
\hline & H31S & C31 22S 17a(H) hopane \\
\hline & Gam & gammacerane \\
\hline & H32S-H35S & C32-C35 22S 17a(H) hopane \\
\hline & H32R-H35R & C32-C35 22R 17a(H) hopane \\
\hline \multirow[t]{5}{*}{217} & S21-S22 & C21-C22 sterane \\
\hline & Dia27S & C27 $\beta \alpha 20$ S diasterane \\
\hline & Dia27R & C27 $\beta \alpha 20 R$ diasterane \\
\hline & S27S-S29S & C27-C29 ad 20R sterane \\
\hline & S27R-S29R & C27-C29 aq 20 S sterane \\
\hline \multirow[t]{2}{*}{218} & S27 $\beta \beta S-S 29 \beta \beta S$ & C27-C29 $\beta \beta 20$ S sterane \\
\hline & S27 $\beta \beta R-S 29 \beta \beta R$ & C27-C29 $\beta \beta$ 20R sterane \\
\hline
\end{tabular}

